\title{
HODNOCENÍ EXEKUTIVNÍCH FUNKCÍ U DĚTí (BRIEF) Recenze metody
}

AutoŘI RECENZE: Petra Hubatková ${ }^{1}$, PATRIK Rudolf ${ }^{1}$

\begin{tabular}{|l|l|}
\hline \multicolumn{1}{|c|}{ datum vzniku recenze: } & 7.12.2020 \\
\hline 1.1 název nástroje: & Hodnocení exekutivních funkcí u dětí \\
\hline \multicolumn{1}{|c|}{ zkrácený název: } & BRIEF \\
\hline 1.2 původní název: & Behavior Rating Inventory of Executive Function \\
\hline 1.4 autoři původního testu: & $\begin{array}{l}\text { Gerard A. Gioia, Peter K. Isquith, Steven C. Guy, Lauren } \\
\text { Kenworthy }\end{array}$ \\
\hline 1.3 autoři lokální adaptace: & Radek Ptáček \\
\hline 1.7 lokální distributor: & Hogrefe-Testcentrum \\
\hline $1.9 .1 / 1.9 .2$ datum vydání: & 2011 \\
\hline
\end{tabular}

Nástroj Hodnocení exekutivních funkcí u dětí (Behavior Rating Inventory of Executive Functions; dále jen BRIEF) slouží ke zhodnocení exekutivních funkcí u dětí ve věku 5-18 let. Exekutivní funkce autoři metody chápou jako soubor "psychických procesů zodpovědných za řízení a ovládání kognitivních, emočních a behaviorálních funkcí, zejména během aktivního řešení nových problémů." Při vývoji metody se autoři opírali o teorii exekutivních funkcí postulovanou např. Stussem a Bensonem (1986), Welshem a kol. (1991) a dalšími.

Metoda BRIEF obsahuje dvě verze dotazníku - jeden pro rodiče a druhý pro učitele. Cílem metody je posouzení exekutivních funkcí dítěte v osmi klinických subškálách: Inhibice, Přesun pozornosti, Emoční kontrola, Iniciativa, Pracovní pamět', Plánování a organizace, Organizace pomůcek a Kontrola chování. Položky tvoří jednotlivá tvrzení popisující chování dítěte, přičemž učitel/rodič hodnotí četnost tohoto chování během posledních šesti měsíců na tř́bodové škále: $\mathrm{N}-N i k d y, 0$ - Občas, Č - Často. Obě verze dotazníku obsahují 86 položek, přičemž verze se zněním položek částečně liší v závislosti na kontextu, ve kterém rodič/učitel má možnost dítě pozorovat. Některé položky se svým zněním překrývají v obou verzích. Klinické škály dále tvoří dva dílčí skóry - Index regulace chování (BRI; tvořen škálami Inhibice, Přesun pozornosti a Emoční kontrola) a Index metakognice (MI; tvořen škálami Iniciativa, Pracovní pamět', Plánování a organizace,

\footnotetext{
${ }^{1}$ Katedra psychologie, Fakulta sociálních studií MU, Joštova 10, 60200 Brno
} 
Organizace pomůcek a Kontrola chování) - a jeden celkový skór Globální exekutivní kompozit (GEC). Pro interpretaci jsou určené jak T-skóry z klinických škál, tak jednotlivé indexy. BRIEF obsahuje také dvě validizační škály - Škálu inkonzistence a Škálu negativity.

\section{Administrace a skórování}

Administrace je možná individuálně i skupinově bud' stylem tužka-papír nebo lze test vyplňovat prostřednictvím počítačové aplikace v rozhraní HTS 5. Odhadovaná doba administrace je 10-15 minut. Při použití metody BRIEF se předpokládá supervidovaná a kontrolovaná administrace kvalifikovaným administrátorem. Vyhodnocování by měl provádět absolvent minimálně bakalářského stupně akreditovaného studijního oboru psychologie, př́padně jiného relevantního oboru jako pediatrie apod. Manuál také zdůrazňuje dostatečnou teoretickou znalost oblasti exekutivních funkcí pro správnou interpretaci a vyhodnocení. Instrukce k administraci a skórování obsažené v manuálu jsou dle našeho názoru dostatečné a srozumitelné.

Počet položek v jednotlivých škálách se liší. Navíc je počet položek pro stejné škály odlišný v jednotlivých verzích metody. Současně z celkových 86 položek jich 13 (verze pro rodiče), resp. 14 (verze pro učitele), není započítáno do hrubých skórů. Odpovědi jsou hodnoceny 1 (pro možnost Nikdy) až 3 body (pro možnost Často). Z nich je pro každou subškálu vypočítán hrubý skór, který je dále dle normativních tabulek převeden na Tskór. Stejný postup se opakuje i pro BRI, MI a GEC. Autoři ale doporučují spíše než indexy interpretovat hrubé skóry z jednotlivých škál. Kromě skóru klinických subškál a kompozitních indexů autoři metody doporučují vypočítat skóry na Škále negativity a Škále inkonzistence. Ty indikují možnost nevalidních odpovědí rodiče/učitele. Skór ve Škále inkonzistence je získán jako součet absolutních rozdílů mezi 10 dvojicemi položek s podobným zněním. Skór menší nebo roven 6 je přijatelný a skór větší nebo roven 9 indikuje možné nevalidní odpovědi. Škála negativity se skládá z devíti položek, u nichž byla ve standardizační studii nízká četnost odpovědi Často. Skór negativity je spočítán jako celkový počet odpovědí Často na těchto devět položek. Skór menší nebo roven 4 je považován za přijatelný, naopak skór vyšší nebo roven 7 za nápadně zvýšený. Čas potřebný ke skórování a vyhodnocení testu ve verzi papír-tužka distributor neuvádí, autory recenze byl odhadnut na 5 a 15 minut. Při administraci prostřednictvím počítače jsou položky skórovány a analyzovány automaticky (včetně validizačních škál) a výsledky respondenta jsou $\mathrm{k}$ dispozici $\mathrm{v}$ generované zprávě. Počítačem generovaná zpráva neposkytuje intervaly spolehlivosti, což považujeme za vážný nedostatek, a ani $\mathrm{v}$ interpretaci skórů $\mathrm{s}$ intervaly nepracuje nebo neupozorňuje na potenciální chybu měření.

\section{Technické parametry}




\section{Normy}

České normy metody BRIEF nejsou dostupné. $V$ rámci české standardizační studie ( $N_{\text {rodiče }}$ = 358, Nučitelé $=358$ ) byly pro srovnání s americkými normami pouze spočítány rozdíly hrubých skórů jednotlivých škál mezi českým a americkým vzorkem. Reportovány jsou tyto rozdíly ale pouze pro jednotlivé věkové kategorie u dívek, nikoli u chlapců.

Autoři české standardizace doporučují pracovat s americkými normami, pro což argumentují především malými rozdíly ve skórech jednotlivých škál mezi jednotlivými věkovými kategoriemi českého standardizačního a amerického normativního vzorku. Absolutní rozdíly v průměrných hrubých skórech mezi českým a americkým souborem se v jednotlivých škálách i indexech pohybují od 0 do 5,83 ve verzi pro rodiče, resp. 0,02 až 4,97 ve verzi pro učitele. Autoři argumentují hlavně nesignifikancí na $5 \%$ hladině významnosti u většiny z nich. Velikosti účinku těchto rozdílů se po dopočítání pohybují v rozmezí $0<$ Cohenovo $d<0,57$ (medián 0,2 ). Např́klad u škály Iniciativa ve verzi pro rodiče je pro jednotlivé věkové skupiny medián Cohenova $d$ roven 0,5 . V př́padě verze pro učitele se nám srovnávání nicméně jeví jako nevhodné, protože věkové kategorie, s nimiž pracovali autoři české standardizace, se plně nepřekrývají s věkovými kategoriemi v americké standardizaci (např. kategorie 8-10 let v české verzi vs. kategorie 7-8 v americké). $V$ př́padě jediného smysluplného porovnání (věková skupina 14-18 let) medián Cohenova $d$ dosahuje 0,29 a u čtyř škál je velikost účinku středně silná až silná $(0,46<$ Cohenovo $d<0,52)$. Odhlédneme-li od toho, že je porovnávání odlišných věkových skupin ve verzi pro učitele samo o sobě problematické, lze konstatovat, že v obou verzích uvedené velikosti rozdílů přinejmenším v některých subškálách nejsou zanedbatelné a mohou poukazovat na jejich odlišné fungování v českém prostředí, které by bylo vhodné ověřit.

Nad rámec výše uvedeného autoři české standardizace argumentují údajnou empiricky prokázanou nezávislostí výsledků na sociokulturním prostředí. Argumentace autorů se nám ale celkově jeví jako nedostatečná. Především nejsou poskytnuty žádné důkazy o ekvivalenci měření (invarianci) české a anglické verze dotazníku. Nelze proto posoudit, zda BRIEF měří $\mathrm{v}$ českých podmínkách ty stejné zamýšlené konstrukty. Americký normativní vzorek byl vybrán, aby reflektoval rozložení klíčových demografických charakteristik (pohlaví, socioekonomický status (SES), etnikum, věk, hustota osídlení) populace USA, nikoli České republiky. Konkrétní informace o složení normativního vzorku jsou navíc podány pouze s ohledem na pohlaví a věk hodnocených dětí. Není jasné, jaké bylo rozložení dalších charakteristik, a proto není možné zhodnotit, zda alespoň přibližně odráží specifika české populace. Uvedené skutečnosti chápeme jako o to problematičtější, že americké normy byly vytvářeny okolo roku 2000. Pro aktuální použití se tak jeví jako potenciálně zastaralé. Krom výše uvedeného navíc autoři americké standardizace zmiňují negativní korelaci skórů ve většině klinických škál jednak se SES, jednak se vzděláním rodičů - děti z rodin s nižším SES a děti rodičů s nižším dosaženým vzděláním tak byly $\mathrm{v}$ průměru hodnoceny hůře. To samo o sobě nepoukazuje na sociokulturní podmíněnost výsledků BRIEF, aby ale bylo možné konstatovat jejich 
sociokulturní nezávislost, bylo by alespoň pro uvedené demografické charakteristiky vhodné ověřit invarianci měření potažmo diferenciální fungování položek BRIEF.

Americký normativní vzorek $\left(N_{\text {rodiče }}=1419, N_{\text {učitelé }}=720\right)$ byl získán na 25 školách v americkém státu Maryland. Normy jsou kvůli zjištěným rozdílům skórů škál BRIEF mezi pohlavími a věkovými kategoriemi rozčleněny do celkem 16 normativních tabulek podle verze (rodiče x učitelé), pohlaví a věku (verze pro rodiče: 5-7, 8-10, 11-13 a 14-18 let; verze pro učitele: $5-6,7-8,9-13$ a 14-18 let). $V$ př́padě verze pro rodiče jsou velikosti výběrů adekvátní ( $N=144-167$ pro jednotlivé věkové kategorie chlapců, $N=161-262$ pro jednotlivé věkové kategorie dívek). $V$ př́ípadě verze pro učitele jsou ovšem ve většině kategorií nedostačující (ve věkových skupinách 5-6 a 7-8 u chlapců a 5-6 u dívek $N<50$, ve věkových skupinách 7-8 u chlapců a 7-8 a 14-18 u dívek $N<100$, pouze ve věkové skupině 9-13 u chlapců $N=162$ a věkové skupině $9-13$ u dívek $N=224$ ).

\section{Validita}

Validita nástroje BRIEF je problematická z několika důvodů. $V$ první řadě vyvstávají otázky ohledně obsahové validity metody. Teoretické východisko dle našeho názoru není dostatečně rozvedeno a vztaženo na testovou metodu a všechny její škály. Manuál pouze velmi povrchně popisuje fungování exekutivních funkcí a krátce nastiňuje různé př́stupy k exekutivním funkcím bez bližšího vztažení k tomu, jak přesně z nich bylo při vývoji testu vycházeno. Také chybí informace o tom, jak byli vybíráni experti a lidé z praxe, kteří poskytnuli příklady typického chování při narušení exekutivních funkcí. Tyto př́ílady se staly základem pro tvorbu položek. Velkou slabinu popisu vývoje metody poté představuje zmatečné vysvětlení způsobu zařazení položek do té které škály a ověření této struktury. Z popisu explorační faktorové analýzy není jasné, jak přesně autoři postupovali, ani nejsou poskytnuty bližší informace o analýze. Autoři uvádí, že v rámci pilotní studie provedli explorační faktorovou analýzu (EFA). Ta byla provedena na 129 položkách od 120 respondentů-rodičů a 127 položkách od 120 respondentů-učitelů. Její přesné výstupy ovšem nejsou reportovány. Současně se domníváme, že takto nízký vzorek je při tak vysokém počtu položek nedostatečný. V EFA byla navíc použita ortogonální rotace, která nám také nepřipadá vzhledem k teorii, ze které autoři vychází, ani následné operaci se skóry vhodná. Současně v navazující studii na rozsáhlejším vzorku už autoři BRIEF předpokládanou faktorovou strukturu neověřovali, pouze zkoumali mezipoložkovou korelaci a korelaci položky s celkovým skóre pro danou škálu. Konfirmační faktorová analýza by nám v tomto kontextu přišla vhodnější. Dohledali jsme ale několik studií, v nichž byla provedena konfirmační faktorová analýza (CFA) se součtovými skóry klinických škál jako manifestními proměnnými (Egeland \& Fallmyr, 2010; Fournet et al., 2014; Gioia et al., 2002; Lyons Usher et al., 2016; Peters et al., 2012). Jejich výsledky poukazují na to, že ani jednoduché jednofaktorové řešení (faktor odpovídající GEC), ani jednoduché řešení se dvěma korelovanými faktory odpovídajícími indexům BRI a MI (sycenými stejnými škálami, z jejichž součtu jsou dle manuálu indexy vytvořeny) nepopisuje data dobře. Validita jak indexů BRI a MI, tak kompozitního skóru GEC, je proto značně problematická. $V$ jedné dohledané studii (Huizinga \& Smidts, 2011) 
byla provedena CFA se samostatnými položkami jako indikátory. Zde bylo podpořeno osmifaktorové řešení odpovídající osmi klinickým škálám (s povolením tří mezipoložkových reziduálních korelací). Některé faktory nicméně vzájemně velmi silně korelovaly (v šesti případech $r>0,75$, z toho ve dvou případech $r>0,85$; i v manuálu spolu některé škály velmi silně korelují - byt' na úrovni součtových skórů) a zároveň nebylo testováno alternativní faktorové řešení. Interpretace skórů z klinických škál je tak vzhledem k velmi omezené empirické podpoře také problematická.

Co se týče samotného vyznění položek, dle našeho pohledu neobsahují žádné významné nejasnosti. Položky jsou formulovány srozumitelně a obtížností na pochopení dle manuálu odpovídají úrovni vzdělání 4. až 5. třídy. Nicméně některé položky mohou být problematické svou formulací nebo i samotným obsahem. Například některé položky se dotazují na dvě věci zároveň (např. „Nedostatečně si uvědomuje své přednosti a slabosti“) nebo jsou formulovány záporně a odpovídání na škále Nikdy-Občas-Často může pro respondenta být náročnější. Dále se domníváme, že některé položky mohou být svým obsahem již irelevantní pro určité skupiny. Např. položka, která se dotazuje, zda je běžné, že si dítě neuklízí hračky, je pro adolescenta nevhodná. Současně položky často vyžadují poměrně detailní představu o fungování dítěte $\mathrm{v}$ různých kontextech, o kterých rodič adolescenta již nemusí mít přehled a jeho odpovědi tak mohou být zkreslené. Položky také mohou fungovat různě nejen na základě věku ale i jiných kategorií (pohlaví, SES, etnikum apod.). Např́iklad položka „Má potíže s dokončením úkolu“ může být problematická $\mathrm{v}$ případě, že dítě žije $\mathrm{v}$ přeplněném, neklidném prostředí a nemá tak vhodné podmínky $\mathrm{k}$ tomu úkol dokončit. $\mathrm{V}$ tomto kontextu považujeme za problematické, že se při vývoji testu tento aspekt nezohlednil a není k dispozici DIF analýza nebo ověření invariance pro různé skupiny. Invariance byla doposud zkoumána pouze pro jednotlivé věkové kategorie na vzorku francouzském (Fournet et al., 2015; plná invariance podpořena pouze na metrické úrovni) a nizozemském vzorku (Huizinga \& Smidts, 2011; podpořena invariance na skalární úrovni).

Konstruktová validita byla dle autorů posuzována pomocí korelací s dalšími dotazníky založenými na principu hodnocení chování dítěte rodičem a/nebo učitelem. Škály BRIEF korelují se škálami použitých měřících nástrojů většinou dle očekávání. Přesto ale manuál obsahuje několik logických inkonzistencí nebo nedostatečných informací. Za prvé se vůbec nevyjadřuje ke vztahu škály Organizace pomůcek. Za druhé selektivně reportuje výsledky korelací - např. u Inhibice se vyjadřuje ke vztahu se škálou Poruch pozornosti Dotazníku Hodnocení Dětského Chování (CBCL), ale nikoliv u podobných škál obsažených v Hodnocení Dětského Chování Učitelem (TRF) a v Hodnocení Dětského Chování (BASC). V neposlední řadě nechává logické inkonzistence bez komentáře - např. Index regulace chování (BRI) z verze pro rodiče měl téměř nulový vztah se Škálou poruch chování v BASC. V př́ípadě verze pro učitele manuál uvádí pouze rozpětí korelací jednotlivých škál se Škálou poruch chování BASC. Tyto korelace byly relativně silné. Jako nedostatek vidíme i to, že se posouzení konstruktové validity nástroje opírá pouze o jiné dotazníkové metody pro rodiče/učitele. Autoři nevyužili žádných výkonových nebo observačních metod pro měření exekutivních funkcí dítěte. Studie, která porovnávala skóry pracovní paměti z 
BRIEF se skóry pracovní paměti získané pomocí WJ-III Cog, zjistila velmi slabý vztah (Milke, 2015). Současně Vriezen a Pigott (2002) nenašli u dětí s traumatickým poraněním mozku žádný vztah mezi indexy BRIEF z verze pro rodiče a výkonovými testy měřícími exekutivní funkce, ačkoliv autoři zdůrazňují možnou nedostatečnou senzitivitu, která v době vzniku studie nebyla pro zvolené výkonové metody v dětské populaci dostatečně prozkoumána.

V neposlední řadě se autoři zabývali porovnáním průměrných skórů mezi klinickými a kontrolními skupinami pro různé vývojové, neurologické, psychiatrické a jiné poruchy. Klinická a kontrolní skupina byla párovaná vždy minimálně na základě věku, pohlaví a SES, v některých př́ípadech i na základě etnika. Bohužel informace ohledně kriteriální validity neposkytují dostatečný obrázek o vhodnosti metody BRIEF. V první řadě, manuál se spíše než na velikost účinku rozdílů mezi klinickými a kontrolními skupinami soustředí na statistickou signifikanci, od které odvíjí argumentaci. Navíc hodnotu velikosti účinku přímo neudává, nicméně ji lze dopočítat z uvedených průměrů a směrodatných odchylek. Přesto ale explicitní neuvedení velikosti účinku značně omezuje uživatelskou př́ivětivost manuálu. Dopočítané korelace mezi skóry na jednotlivých škálách, resp. indexech, se pohybují v rozmezí $0 \leq r<0,91$; v průměru jsou korelace středně silné (medián odpovídá $0,44)$. V řadě druhé - manuál neuvádí, jaké vztahy mezi skóry na škálách (resp. indexech) BRIEF u té které poruchy očekává a pouze reportuje signifikantní rozdíly bez vztažení $\mathrm{k}$ teorii. Například informace uvedené u včasně léčené fenylketonurie (PKU) mohou vyznívat tak, že pacienti s PKU mají problém pouze s úzkým výsekem exekutivních funkcí. Nicméně studie, které pracovaly s výkonovými testy uvádí snížený výkon v několika oblastech exekutivních funkcí, včetně inhibice, pracovní paměti, přesunu pozornosti nebo i v otázce řešení úkolů (ačkoliv údaje pro poslední dvě složky se výsledky napříč studiemi liší; Christ et al., 2010). Rozdíly ve většině škál a indexů mezi pacienty s PKU a kontrolní skupinou jsou ale u BRIEF verze pro rodiče nejen statisticky nevýznamné, ale také poměrně slabé $(0,01<r<0,35$; medián korelací 0,08$)$. Poměrně slabý vztah skórů u verze pro rodiče je i u pacientů s vážným traumatickým poraněním mozku v porovnání s hospitalizovanými ortopedickými pacienty $(0,03<r<0,28$; medián korelací 0,23$)$, u mentální retardace $(0 \leq r<0,52$; medián korelací 0,22$)$ a u dětí s nízkou porodní váhou v porovnání s dětmi narozenými v termínu (pro extrémně nízkou porodní váhu: $0,08<r$ $<0,35$; medián korelací 0,27; pro velmi nízkou porodní váhu: 0,01 $<r<0,13$; medián korelací 0,1). Naopak středně silné až silné jsou vztahy mezi skóry na škálách i indexech (ve verzi pro rodiče) a diagnostikovanou poruchou pro ADHD (pro ADHD-I: 0,11< $r<$ 0,66; medián korelací 0,47; pro ADHD-C 0: $44<r<0,68$; medián korelací 0,52), vysokofunkční autismus $(0,6<r<0,91$; medián korelací 0,85$)$ a pervazivní vývojové poruchy $(0,31<r<0,66$; medián korelací 0,5$)$. Obdobný trend lze pozorovat i u verze pro učitele (ADHD-I: 0,32 $<r<0,63$; medián korelací 0,48; ADHD-C: 0,42 $<r<0,65$; medián korelací 0,58, vysokofunkční autismus: 0,42 $<r<0,7$; medián korelací 0,56; pervazivní vývojové poruchy: $0,36<r<0,62$; medián korelací 0,56 ). Nakonec jako vážný nedostatek u kriteriální validity vidíme i nerovnoměrné ověření verze pro učitele a pro rodiče 
v různých skupinách (verze pro rodiče ověřena ve všech skupinách, verze pro učitele pouze u ADHD, vysokofunkčního autismu a pervazivních vývojových poruch).

Co se týče validizačních škál (Škála inkonzistence a Škála negativity) autoři neuvádějí žádné důkazy jejich validity. V př́padě Škály inkonzistence dle našeho názoru rozdíly v odpovědích na dvojice podobně formulovaných položek nemusí nutně indikovat inkonzistenci v odpovídání respondenta. Některé dvojice položek se svým zněním liší natolik, že mohou vyjadřovat jinou fasetu měřeného konstruktu (např. Vyrušuje ostatní. a Mluví, když nemá.) nebo mohou být různě obtižné (např. Mívá záchvaty vztahu a je výbušný/á. a Vzteká se kvůli maličkostem.) a nekonzistence v odpovědích na takové položky tak může být spíše důsledkem těchto faktorů. V př́ípadě položek Škály negativity byla ve standardizační studii poměrně málo volena odpověd' Často. Vysoká četnost těchto odpovědí, tak může dle autorů poukazovat na výjimečně negativní percepci dítěte ze strany posuzujícího. Autoři ale zároveň uvádějí, že vysoký skór na Škále negativity může reflektovat i skutečně silné narušení exekutivních funkcí dítěte. Možnost nevalidních odpovědí vyplývající $\mathrm{z}$ obou škál by proto $\mathrm{z}$ našeho pohledu měla být interpretována obezřetně a s přihlédnutím $\mathrm{k}$ dalším dostupným informacím o dítěti. Autoři manuálu doporučují se $\mathrm{v}$ případě podezření na nevalidní odpovědi doptat respondenta na okolnosti nekonzistentního/negativního odpovídání.

\section{Reliabilita}

Autoři jak americké, tak české standardizační studie uvádí pouze rozpětí odhadů vnitřní konzistence (koeficient alfa) napříč subškálami a kompozitními skóry. Rozpětí odhadů prezentované v manuálu jsou navíc spočítané pro celý soubor napříc věkem, a jsou tedy pravděpodobně nadhodnocené. Tyto odhady vnitřní konzistence se pohybují v rozmezí $0,80-0,98$ v prrípadě americké standardizace a $0,81-0,92$ v případě české standardizace. Odhady vnitřní konzistence pro jednotlivé subškály a kompozitní skóry lze nicméně zpětně dopočítat $\mathrm{z}$ hodnot pro výpočet $90 \%$ intervalů spolehlivosti, které jsou uvedeny $\mathrm{v}$ tabulkách norem, a to i pro jednotlivé věkové skupiny zvlášt'. Z nich lze dovodit, že vnitřní konzistence některých subškál $v$ určitých věkových skupinách je nižší než 0,8 (napřr. subškála Iniciativa, chlapci 8-10 let, verze pro rodiče), v některých př́ípadech se dokonce pohybuje okolo hodnoty 0,7 (napřr. subškála Organizace pomůcek, chlapci 14-18 let, verze pro učitele). Informace uvedené v manuálu tak nejsou plně v souladu s informacemi $v$ tabulkách norem. Vnitřní konzistence indexů BRI a MI a celkového skóru GEC je ale pro všechny věkové skupiny a obě verze dotazníku velmi dobrá (nejnižší hodnoty se pohybují okolo 0,91 ).

Test-retest reliabilita byla posuzována ve dvou podskupinách (normativní a klinická) u verze pro rodiče (časový rozestup 2-3 týdnů) a jedné podskupině (z manuálu není jasné, zda šlo o normativní nebo klinickou) u verze pro učitele (časový rozestup 3,5 týdne). Medián test-retest korelací pro klinické škály přesahuje ve všech př́padech hodnotu 0,8, to samé platí i pro indexy BRI, MI a kompozitní skór GEC. Velikosti test retest-korelací se zdají být velmi dobré, mohly být ale zkresleny (potažmo nadhodnoceny) jednak poměrně 
krátkými časovými rozestupy mezi jednotlivými administracemi, jednak relativně malými velikostmi vzorku ( $N=40-54)$, které mohly vést k nepřesnému odhadu. V př́ípadě české standardizace jsou uvedeny pouze průměrné rozdíly skórů bez odhadů test-retest reliability. U těchto rozdílů navíc není jasné, zda jde o rozdíl hrubých skórů nebo T-skórů.

V případě alternativních forem BRIEF (verze pro rodiče, verze pro učitele) nelze hovořit o paralelních testech ani míře paralelnosti v pravém slova smyslu. Verze jednak obsahují část položek rozdílných, jednak je počet položek u většiny škál odlišný v jedné a druhé verzi, jednak je každá verze hodnocena odlišným hodnotitelem (rodič/učitel). Autoři americké standardizace uvádějí korelace jednotlivých škál mezi oběma verzemi spočítané na vzorku $N=296$. V případě klinických škál jsou korelace mezi verzí pro rodiče a pro učitele u čtyř z nich nižší než 0,2 , u dvou se pohybují okolo 0,3 , a pouze u dvou jsou vyšší než 0,4 . Korelace BRI, MI a GEC přesahují ve všech třech př́ípadech mírně hodnotu 0,3. Vzájemné korelace škál mezi verzí pro rodiče a pro učitele tak nelze považovat za adekvátní. Jejich interpretace je ale vzhledem k odlišnostem obou verzí problematická a nelze ji chápat ani jako korelaci paralelních testů, ani jako shodu posuzovatelů v pravém slova smyslu. Jde spíše o ukazatel konvergentní validity - i z tohoto pohledu jsou vzájemné korelace poměrně slabé a poukazují na problematičnost možnosti srovnatelné interpretace skórů v obou verzích.

\section{Shrnutí}

BRIEF představuje relativně snadno administrovatelný nástroj pro posouzení dílčích aspektů exekutivních funkcí u dětí a dospívajících ve věku 5-18 let. Metoda má potenciál být užitečným screeningovým nástrojem $\mathrm{v}$ neuropsychologické a poradenskopsychologické diagnostice díky relativní srozumitelnosti položek a snadné proceduře administrace a vyhodnocování. Informace poskytnuté dodavatelem k administraci a vyhodnocování BRIEF jsou dostatečné. Standardizace původní i české verze BRIEF nicméně trpí několika zásadními nedostatky, na základě kterých lze doporučit využití metody v diagnostické praxi pouze ve velmi omezených aplikačních oblastech (viz Závěr).

V manuálu jsou nedostatečně uvedeny důkazy o faktorové validitě BRIEF. Není proto jasné, zda skóry jednotlivých škál skutečně vyjadřují zamýšlené konstrukty. Autoři manuálu v tomto ohledu pouze chybně argumentují vysokými hodnotami koeficientů alfa (viz např. Marko, 2016), které podle nich poukazují na to, že položky škály měří tentýž konstrukt. Interpretace skórů, tak jak je doporučována v manuálu (tj. jednak na úrovni osmi klinických škál, jednak na úrovni indexů BRI a MI, jednak na úrovni celkového skóru GEC), je kvůli absenci důkazů o faktorové struktuře problematická. Závěry několika studií (viz sekci Validita) navíc dokládají, že empirická struktura BRIEF se spíše liší od dimenzí navrhovaných v manuálu. To značně limituje možnosti interpretace jednotlivých skórů.

Za naprosto zásadní nedostatek české verze BRIEF pokládáme absenci lokálních norem pro Českou republiku. Americké normy nepovažujeme vzhledem $\mathrm{k}$ jejich neporovnatelnosti co do demografických charakteristik a zastaralosti za vhodné pro 
využívání v českém prostředí. Velikosti rozdílů mezi českým a americkým vzorkem v průměrech subškál navíc naznačují, že mohou některé subškály v českém prostředí fungovat jinak než $\mathrm{v}$ americkém. Využívání amerických norem se proto nezdá být adekvátní. Americké normy jsou navíc v případě verze BRIEF pro učitele založeny u většiny věkových kategorií na velmi malých vzorcích.

Pro férové využívání testu by navíc bylo vhodné získat informace o diferenciálním fungování položek a invarianci měření. Invariance byla doposud zkoumána pouze pro jednotlivé věkové kategorie na vzorku francouzském (Fournet et al., 2014; plná invariance podpořena pouze na metrické úrovni) a nizozemském vzorku (Huizinga \& Smidts, 2011; podpořena invariance na skalární úrovni). Za nezbytné ale považujeme získání důkazů také o invarianci pro pohlaví, různé úrovně SES rodiny nebo etnické menšiny ( $\mathrm{v}$ ČR např. romské a vietnamské populace).

V americkém prostředí je k dispozici již druhá revize BRIEF-2, která se od první verze liší hlavně pozměněným počtem a interpretací subškál i dílčích indexů. Také je metoda kromě verze dotazníku pro rodiče a učitele rozšířena o sebeposuzovací dotazník pro děti a adolescenty ve věku od 11 do 18 let. Oproti BRIEF do BRIEF-2 nebyly přidány žádné položky, jednotlivé verze ale mají být vzájemně více paralelní. Současně druhá revize oproti první obsahuje navíc 12položkové screeningové formuláře pro učitele, rodiče i pro samotné děti/adolescenty.

\section{Závěr}

Vzhledem k nedostatečným důkazům o faktorové struktuře BRIEF, a tudíž i o možnostech interpretace jednotlivých skórů, a kvůli chybějícím českým normám doporučujeme využívat BRIEF $\mathrm{v}$ běžné diagnostické praxi pouze ve velmi omezených aplikačních oblastech. Dle našeho názoru může být metoda BRIEF užitečná pouze jako nástroj pro prvotní screening potenciálního narušení exekutivních funkcí. Výsledky by ale měl být interpretovány nanejvýš obezřetně a informace získané administrací BRIEF by měly být vždy dávány do souvislosti $\mathrm{s}$ dalšími zdroji informací získaných během vyšetření. Rozhodně ale nelze BRIEF považovat za ukazatel kvality exekutivních funkcí v jednotlivých doménách fungování. Pro účel jednoznačnější interpretace výsledků BRIEF je nezbytné provést důkladnější českou standardizaci zahrnující sestavení norem reflektujících demografické charakteristiky České republiky. Je také nutné získat důkazy o validitě BRIEF a invarianci metody pro různé skupiny. Vzhledem k již publikované druhé verzi metody (BRIEF-2; Gioia et al., 2015) je ale otázkou, zda by nebylo vhodnější zohlednit uvedené prvky spíše v případné standardizaci této nové verze.

\section{Zdroje}

Egeland, J., \& Fallmyr, Ø. (2010). Confirmatory factor analysis of the Behavior Rating Inventory of Executive Function (BRIEF): Support for a distinction between emotional 
and behavioral regulation. Child Neuropsychology, 16(4), 326-337.

https://doi.org/10.1080/09297041003601462

Fournet, N., Roulin, J.-L., Monnier, C., Atzeni, T., Cosnefroy, O., Gall, D., \& Roy, A. (2014). Multigroup confirmatory factor analysis and structural invariance with age of the Behavior Rating Inventory of Executive Function (BRIEF)-French version. Child Neuropsychology, 21(3), 1-20. https://doi.org/10.1080/09297049.2014.906569

Gioia, G. A., Isquith, P. K., Guy, S. C., \& Kenworthy, L. (2015). Behavior Rating Inventory of Executive Function, Second Edition. Psychological Assessment Resources.

Gioia, G. A., Isquith, P. K., Retzlaff, P. D., \& Espy, K. A. (2002). Confirmatory factor analysis of the Behavior Rating Inventory of Executive Function (BRIEF) in a clinical sample. Child Neuropsychology, 8(4), 249-257. https://doi.org/10.1076/chin.8.4.249.13513

Huizinga, M., \& Smidts, D. P. (2011). Age-related changes in executive function: A normative study with the Dutch version of the Behavior Rating Inventory of Executive Function (BRIEF). Child Neuropsychology, 17(1), 51-66. https://doi.org/10.1080/09297049.2010.509715

Christ, S. E., Huijbregts, S. C. J., de Sonneville, L. M. J., \& White, D. A. (2010). Executive function in early-treated phenylketonuria: Profile and underlying mechanisms.

Molecular Genetics and Metabolism, 99, 22-32. https://doi.org/10.1016/j.ymgme.2009.10.007

Lyons Usher, A. M., Leon, S. C., Stanford, L. D., Holmbeck, G. N., \& Bryant, F. B. (2016). Confirmatory factor analysis of the Behavior Rating Inventory of Executive Functioning (BRIEF) in children and adolescents with ADHD. Child Neuropsychology, 22(8), 907-918. https://doi.org/10.1080/09297049.2015.1060956

Marko, M. (2016). Využitie a zneužitie Cronbachovej alfy pri hodnotení psychodiagnostických nástrojov. Testfórum, 5(7), 99-107. https://doi.org/10.5817/TF2016-7-90

Milke, R. M. (2015). Working memory: The concurrent validity of the Behavior Rating Inventory of Executive Function and the relationship between parent and teacher ratings and performance-based measures. [Dizertační práce]. Indiana University.

Peters, C., Algina, J., Smith, S. W., \& Daunic, A. P. (2012). Factorial validity of the Behavior Rating Inventory of Executive Function (BRIEF)-Teacher form. Child Neuropsychology, 18(2), 168-181. https://doi.org/10.1080/09297049.2011.594427

Stuss, D. T., \& Benson, D. F. (1986). The frontal lobes. Raven Press.

Vriezen, E. R., \& Pigott, S. E. (2002). The relationship between parental report on the BRIEF and performance-based measures of executive function in children with 
moderate to severe traumatic brain injury. Child Neuropsychology, 8(4), 296-303. https://doi.org/10.1076/chin.8.4.296.13505

Welsh, M. C., Pennington, B. F., \& Groisser, D. B. (1991). A normative-developmental study of executive function: A window on prefrontal function in children. Developmental Neuropsychology, 7(2), 131-149. https://doi.org/10.1080/87565649109540483 


\author{
EFPA \\ STANDING COMMITTEE ON \\ TESTS AND TESTING (SCTT)
}

Příloha ke Zprávě předsedy, 2005

MODEL RECENZE PODLE EFPA PRO POPIS

A HODNOCENÍ PSYCHOLOGICKÝCH TESTŮ

FORMULÁŘ RECENZE TESTU A POZNÁMKY PRO RECENZENTY

Verze 3.42

Lokální úprava pro časopis Testforum

ISSN 1805-9147 


\section{MODEL RECENZE PODLE EFPA PRO POPIS \\ A HODNOCENÍ PSYCHOLOGICKÝCH TESTŮ \\ FORMULÁŘ RECENZE TESTU A POZNÁMKY PRO \\ RECENZENTY ${ }^{1}$}

Toto je lokální úprava dokumentu pro účely publikace v časopise Testfórum.

Originální český překlad je k dispozici na stránkách EFPA

(www.efpa.eu/download/505cd9db4144ecb16174087909c9cd6d).

Původní verzi sestavil a uspořádal Dave Bartram

Doplnili a revidovali Patricia Lindley, Dave Bartram a Natalie Kennedy v dubnu $2004^{2}$

Současná verze 3.42: květen 2005

Český překlad: Tomáš Urbánek

Od uživatelů tohoto dokumentu a jeho obsahu žádá EFPA, aby uznali tento zdroj prostřednictvím následujícího textu:

"Kritéria pro recenzi testu podle EFPA do značné míry vychází z formy a obsahu kritérií pro recenze testů Britské psychologické společnosti (BPS) a kritérií vytvořených Komisí pro testové záležitosti (COTAN) Holandské asociace psychologů (NIP). Dave Bartram a Patricia Lindley původně vyvinuli kritéria BPS a recenzní procedury pro UK Employment Service a později rozšírili jejich používání pro celou BPS. Arne Evers připravil k vydání nizozemský system posuzování kvality testů.

EFPA je vděčná BPS a NIP za svolení použít jejich kritéria jako základ pro vytvoření evropského modelu. EFPA je také vděčná Davu Bartramovi, Arnu Eversovi a Patricii Lindley za jejich přispění $k$ vývoji tohoto modelu. Veškerá intelektuální vlastnická práva původních kritérií podle BPS a NIP jsou nadále uznávána a náleží těmto orgánům."

\footnotetext{
1 Tento dokument byl vytvořen z několika zdrojů, včetně Hodnotícího formuláře pro recenzi testu používaného v BPS (NPAL a Řídící komise pro testové standardy při BPS - Steering Committee on Test Standards), Španělského dotazníku pro hodnocení psychometrických testů (Španělská psychologická asociace) a Systému pro posuzování kvality testu (Komise pro testování Holandské asociace psychologů). Některé části byly adaptovány se svolením z dokumentu: BPS Books Reviews of Level B Assessment Instruments for use in Occupational Assessment, Notes for Reviewers: Version 3.1. December 1998: Copyright (C) NPAL, 1989, 1993, 1998.

2 Současná verze je spojením dvou oddělených dokumentů (Formuláře recenze a Poznámek pro recenzenty). Obsah byl navíc uspořádán a doplněn na základě jeho používání recenzenty online testů v BPS.
} 


\section{Část 1:}

Popis nástroje: Obecné informace a klasifikace

\begin{tabular}{|c|c|c|}
\hline & Recenzent 1: & Petra Hubatková \\
\hline & Recenzent 2: & Patrik Rudolf \\
\hline & Konzultující editor: & Hynek Cígler \\
\hline & Vedoucí editor: & Jaroslav Gottfried \\
\hline & $\begin{array}{l}\text { Vedoucí editor aktualizace: } \\
\text { (pouze v př́ípadě aktualizací) }\end{array}$ & \\
\hline & $\begin{array}{l}\text { Editor aktualizace: } \\
\text { (pouze v př́ípadě aktualizací) }\end{array}$ & \\
\hline & Datum vzniku této recenze: & 7. 12. 2020 \\
\hline 1.1 & Název nástroje (lokální verze): & Hodnocení exekutivních funkcí u dětí \\
\hline & Zkrácená verze názvu testu: & BRIEF \\
\hline 1.2 & $\begin{array}{l}\text { Původní název testu (pokud je lokální } \\
\text { verze adaptací): }\end{array}$ & $\begin{array}{l}\text { Behavior Rating Inventory of Executive } \\
\text { Function }\end{array}$ \\
\hline 1.4 & Autoři původního testu: & $\begin{array}{l}\text { Gerard A. Gioia, Peter K. Isquith, Steven C. } \\
\text { Guy, Lauren Kenworthy }\end{array}$ \\
\hline 1.3 & Autoři lokální adaptace: & Radek Ptáček \\
\hline 1.7 & Lokální distributor/vydavatel testu: & Hogrefe - Testcentrum \\
\hline 1.8 & $\begin{array}{l}\text { Vydavatel původní verze testu (pokud je } \\
\text { jiný než současný distributor/vydavatel): }\end{array}$ & PAR, Inc. \\
\hline 1.9 .1 & Datum vydání současné revize/vydání: & 2000 \\
\hline 1.9 .2 & $\begin{array}{l}\text { Datum vydání adaptace pro lokální } \\
\text { užívání: }\end{array}$ & 2011 \\
\hline 1.9 .3 & Datum vydání původního testu: & 2000 \\
\hline
\end{tabular}




\section{Obecný popis nástroje}

Nástroj Hodnocení exekutivních funkcí u dětí (Behavior Rating Inventory of Executive Functions; dále jen BRIEF) slouží ke zhodnocení exekutivních funkcí u dětí ve věku 5-18 let. Exekutivní funkce autoři metody chápou jako soubor "psychických procesů zodpovědných za řízení a ovládání kognitivních, emočních a behaviorálních funkcí, zejména během aktivního řešení nových problémů." Při vývoji metody se autoři opírali o teorii exekutivních funkcí postulovanou např. Stussem a Bensonem (1986), Welschem a kol. (1991) a dalšími.

Metoda BRIEF obsahuje dvě verze dotazníku - jeden pro rodiče a druhý pro učitele. Cílem metody je posouzení exekutivních funkcí dítěte v osmi klinických subškálách: Inhibice, Přesun pozornosti, Emoční kontrola, Iniciativa, Pracovní pamět', Plánování a organizace, Organizace pomůcek a Kontrola chování. Položky tvoří jednotlivá tvrzení popisující chování dítěte, přičemž učitel/rodič hodnotí četnost tohoto chování během posledních šesti měsíců na tříbodové škále: $N-N i k d y, O-O b c ̌ a s, \check{C}-$ Často. Odpovědi jsou hodnoceny 1 (pro možnost Nikdy) až 3 body (pro možnost Často), z nichž se vypočítává hrubý skór pro každou ze subškál. Obě verze dotazníku obsahují 86 položek, přičemž verze se zněním položek liší v závislosti na kontextu, ve kterém rodič/učitel má možnost dítě pozorovat. Některé položky se svým zněním překrývají v obou verzích. Klinické škály dále tvoří dva dílčí skóry - Index regulace chování (BRI) a Index metakognice (MI) - a jeden celkový skór Globální exekutivní kompozit (GEC). Pro interpretaci jsou určené jak T-skóry z klinických škál, tak jednotlivé indexy. BRIEF obsahuje i dvě validizační škály - Škálu inkonzistence a Škálu negativity. Při použití metody BRIEF se předpokládá supervidovaná a kontrolovaná administrace kvalifikovaným administrátorem. Vyhodnocování by měl provádět absolvent minimálně bakalářského stupně akreditovaného studijního oboru psychologie, př́padně jiného relevantního oboru jako pediatrie apod. Manuál také zdůrazňuje dostatečnou teoretickou znalost oblasti exekutivních funkcí pro správnou interpretaci a vyhodnocení.

Administrace je možná individuálně i skupinově bud' stylem tužka-papír nebo lze test vyplňovat prostřednictvím počítače. Odhadovaná doba administrace je 10-15 minut. Čas potřebný $\mathrm{k}$ vyhodnocení distributor testu neuvádí, autory recenze byl odhadnut na 5-15 minut. 
Část 2:

Klasifikace

\begin{tabular}{|c|c|c|}
\hline 1.10 .1 & Obsahová doména & $\begin{array}{ll} & \text { Školní schopnosti } \\
\square & \text { Všeobecné schopnosti } \\
\square & \text { Verbální schopnosti } \\
\square & \text { Numerické schopnosti } \\
\square & \text { Prostorové schopnosti } \\
\square & \text { Neverbální schopnosti } \\
\square & \text { Rychlost vnímání } \\
\square & \text { Pamět' } \\
\square & \text { Manuální zručnost } \\
\square & \text { Osobnost - Rys } \\
\square & \text { Osobnost - Typ } \\
\square & \text { Osobnost - Stav } \\
\square & \text { Kognitivní styly } \\
\square & \text { Motivace } \\
\square & \text { Hodnoty } \\
\square & \text { Zájmy } \\
\square & \text { Přesvědčení } \\
\square & \text { Poruchy a patologie } \\
\square & \text { Skupinové procesy } \\
\square & \text { Rodina } \\
\square & \text { Organizace, její fungování, agregovaná } \\
\text { měření, klima atd. } \\
\square \text { Školní nebo výchovné funkce } \\
\bigotimes \quad \text { Jiné: } \\
\text { Test se zaměřuje na měření } \\
\text { exekutivních funkcí, především v } \\
\text { oblasti regulace chování a } \\
\text { metakognice. }\end{array}$ \\
\hline 1.10 .2 & $\begin{array}{l}\text { Zamýšlená(é) nebo hlavní oblast(i) } \\
\text { použití. }\end{array}$ & $\begin{array}{ll}\square & \text { Klinická psychologie } \\
\bigotimes & \text { Neuropsychologie } \\
\square & \text { Forenzní psychologie } \\
\bigotimes & \text { Psychologie výchovy a vzdělávání } \\
\square & \text { Psychologie práce a personalistika } \\
\bigotimes & \text { Poradenství, doporučení, vedení a volba } \\
& \text { povolání } \\
\square & \text { Psychologie zdraví, životní styl a životní } \\
& \text { spokojenost } \\
\square & \text { Sporty a volný čas } \\
\square & \text { Jiné: } \\
& \text { popište }\end{array}$ \\
\hline
\end{tabular}




\begin{tabular}{|c|c|c|}
\hline 1.10 .3 & $\begin{array}{l}\text { Zamýšlený způsob použití } \\
\text { (podmínky, za jakých byl nástroj } \\
\text { standardizován a validizován) }\end{array}$ & $\begin{array}{l}\square \\
\text { Nesupervidovaná administrace bez } \\
\text { kontroly nad identitou respondenta a bez } \\
\text { úplné kontroly nad podmínkami } \\
\text { administrace (např. volně př́stupný test } \\
\text { na internetu, test dostupný ke koupi v } \\
\text { knihkupectví). } \\
\text { Kontrolovaný nesupervidovanou } \\
\text { administrací. Kontrola nad podmínkami } \\
\text { (čas atd.) a určitá kontrola nad identitou } \\
\text { uživatele testu (např. testy } \\
\text { administrované přes internet, ale pouze } \\
\text { známým osobám - př́istup omezený } \\
\text { heslem). } \\
\text { Supervidovaná a kontrolovaná } \\
\text { administrace. Administrace testu pod } \\
\text { kontrolou kvalifikovaného adminitrátora } \\
\text { nebo dohlížitele. } \\
\text { Řízená administrace. Administrace testu } \\
\text { prováděná pouze přes určená testovací } \\
\text { centra (např. programy hodnocení licencí } \\
\text { a certifikace). }\end{array}$ \\
\hline 1.10 .4 & $\begin{array}{l}\text { Popis populací, pro které je test } \\
\text { určen: }\end{array}$ & $\begin{array}{l}\text { Děti ve věku 5-18 let, a to včetně dětí } \\
\text { s různými vývojovými, neurologickými, } \\
\text { psychiatrickými a jinými obtížemi. }\end{array}$ \\
\hline 1.10 .5 & $\begin{array}{l}\text { Počet škál a krátký popis } \\
\text { proměnné nebo proměnných } \\
\text { měřených nástrojem }\end{array}$ & $\begin{array}{l}\text { BRIEF obsahuje celkem osm klinických škál a } \\
\text { dvě škály validizační. } \\
\text { Klinické škály: } \\
\text { Inhibice, Přesun pozornosti, Emoční kontrola, } \\
\text { Iniciativa, Pracovní pamět', Plánování a } \\
\text { organizace, Organizace pomůcek a Kontrola } \\
\text { chování. } \\
\text { Klinické škály tvoří dva dílčí indexy - Index } \\
\text { regulace chování (Inhibice, Přesun } \\
\text { pozornosti, Emoční kontrola) a Index } \\
\text { metakognice (Iniciativa, Pracovní pamět', } \\
\text { Plánování a organizace, Organizace pomůcek } \\
\text { a Kontrola chování) - a jeden celkový skór } \\
\text { Globální exekutivní kompozit. } \\
\text { Validizační škály: } \\
\text { Škála inkonzistence a Škála negativity }\end{array}$ \\
\hline
\end{tabular}




\begin{tabular}{|c|c|c|}
\hline 1.11 & Formát položek & $\begin{array}{ll}\square & \text { Otevřený } \\
\square & \text { Mnohonásobná volba, alternativy na } \\
& \text { stejné škále } \\
\square & \text { Bipolární adjektiva } \\
\bigotimes & \text { Likertovy ratingy (škály) } \\
\square & \text { Nucená volba, alternativy na smíšených } \\
\text { škálách (ipsativní) - vysvětlení viz } \\
\text { Poznámky } \\
\square \text { Mnohonásobná volba, alternativy na } \\
\text { smíšených škálách (ipsativní) - } \\
\text { vysvětlení viz Poznámky } \\
\square \text { Sady párů adjektiv (sémantický } \\
\text { diferenciál), smíšené škály (ipsativní) } \\
\square \text { Jiné: }\end{array}$ \\
\hline 1.12 & Počet položek testu: & $\begin{array}{l}\text { Test obsahuje } 86 \text { položek ve verzi pro rodiče } \\
\text { a } 86 \text { položek ve verzi pro učitele. Jedná se vždy } \\
\text { o výroky, které popisují chování dítěte a } \\
\text { rodič/učitel hodnotí četnost tohoto chování. } \\
\text { Položky ve verzi pro učitele a ve verzi pro } \\
\text { rodiče se liší kontextem, ve kterém rodič nebo } \\
\text { učitel mají možnost dítě pozorovat. Ve verzi } \\
\text { pro rodiče jsou dílčí i celkové skóry počítány } \\
\text { ze } 72 \text { položek, resp. ze } 73 \text { ve verzi pro učitele. } \\
\text { Zbylé položky slouží pouze pro případné } \\
\text { plánování funkční intervence nebo jsou dle } \\
\text { autorů důležité kvůli významnosti pro } \\
\text { specifické populace. }\end{array}$ \\
\hline 1.13 & Způsob(y) administrace: & $\begin{array}{ll}\square & \text { Interaktivní individuální administrace } \\
\square & \text { Supervidovaná skupinová administrace } \\
\square & \text { Počítačová lokálně nainstalovaná } \\
& \text { aplikace - pod supervizí/dohledem } \\
\square & \text { Počítačová aplikace na webu - pod } \\
\text { supervizí/dohledem } \\
\square & \text { Počítačová lokálně nainstalovaná } \\
\text { aplikace - bez supervise/testování sebe } \\
\square \\
\text { Počítačová aplikace na webu - bez } \\
\text { supervize/testování sebe } \\
\square & \text { Jiné: }\end{array}$ \\
\hline 1.14 & Způsob odpovídání: & $\begin{array}{ll}\square & \text { Ústní rozhovor } \\
\bigotimes & \text { Papír a tužka } \\
\square & \text { Manuální operace } \\
\bigotimes & \text { Na počítači } \\
\square & \text { Jiné: }\end{array}$ \\
\hline
\end{tabular}




\begin{tabular}{|c|c|c|}
\hline 1.15 & $\begin{array}{l}\text { Čas potř̌ebný pro administraci } \\
\text { nástroje: } \\
\text { Čas na př́ípravu (čas, který zabere } \\
\text { administrátorovi připravit a rozložit } \\
\text { materiály pro diagnostické sezení). } \\
\text { - Čas na administraci na sezení: zahrnuje } \\
\text { čas potřebný pro dokončení všech } \\
\text { položek a odhad času potřebného pro } \\
\text { podání instrukcí, projití zácvičných } \\
\text { položek a nějaké doplňující komentáře } \\
\text { na konci sezení. } \\
\text { - Skórování: čas nutný pro získání } \\
\text { hrubých skórů. } \\
\text { - Analýza: čas strávený prováděním } \\
\text { dalších prací s hrubými skóry, aby se z } \\
\text { nich odvodily další míry a zformulovala } \\
\text { rozumně úplná interpretace (za } \\
\text { předpokladu, že znáte nástroj). } \\
\text { Zpětná vazba: čas potřebný k př́ípravě a } \\
\text { poskytnutí zpětné vazny vyšetřované } \\
\text { osobě. } \\
\text { Připouští se, že čas posledních dvou } \\
\text { komponent se může značně lišiti - v závislosti } \\
\text { na kontextu, ve kterém se nástroj používá. } \\
\text { Ale aspoň nějaké údaje a komentáře budou } \\
\text { užitečné. }\end{array}$ & 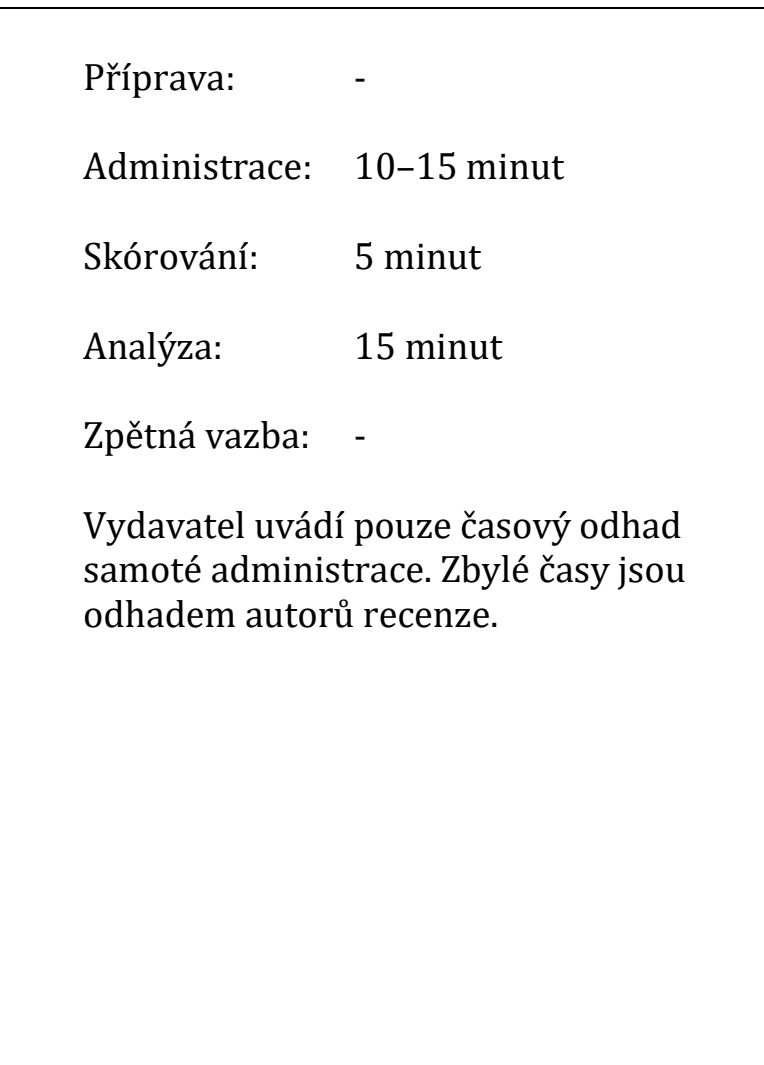 \\
\hline 1.16 & $\begin{array}{l}\text { Jsou k dispozici různé formy } \\
\text { nástroje? }\end{array}$ & $\begin{array}{l}\text { BRIEF obsahuje } 2 \text { verze dotazníku - jednu pro } \\
\text { rodiče, druhou pro učitele. Formy nejsou } \\
\text { zcela ekvivalentní. Většina položek je v obou } \\
\text { verzích stejná, ale část z nich se svým zněním } \\
\text { liší.. Znění položek, ze kterých se počítají } \\
\text { výsledné skóry, jsou shodné v } 55 \text { případech } \\
\text { (šest pro Inhibici, sedm pro Přesun } \\
\text { pozornosti, devět pro Emoční kontrolu, čtyři } \\
\text { pro Iniciativu, devět pro Pracovní pamět', } \\
\text { devět pro Plánování a organizace, čtyři pro } \\
\text { Organizaci pomůcek a sedm pro Kontrolu } \\
\text { chování). Jednotlivé verze se také liší počtem } \\
\text { položek přiřazených k jednotlivým } \\
\text { subškálám. } \\
\text { Existuje také již druhá, revidovaná verze } \\
\text { BRIEF-2 (Gioia et al., 2015) v angličtině. } \\
\text { Revize ale zatím není adaptovaná do českého } \\
\text { prostředí. BRIEF-2 obsahuje kromě verze pro } \\
\text { učitele a rodiče, také self-report variantu pro } \\
\text { starší děti a adolescenty. Nezávisle na druhé } \\
\text { revizi také existuje verze pro předškolní děti } \\
\text { a verze pro dospělé. Ani tyto varianty nebyly } \\
\text { zatím adaptovány do českého prostředí. }\end{array}$ \\
\hline
\end{tabular}




\section{Č́st 3:}

\section{Měření a skórování}

\begin{tabular}{|c|c|c|}
\hline 1.17 & Procedura skórování testu: & 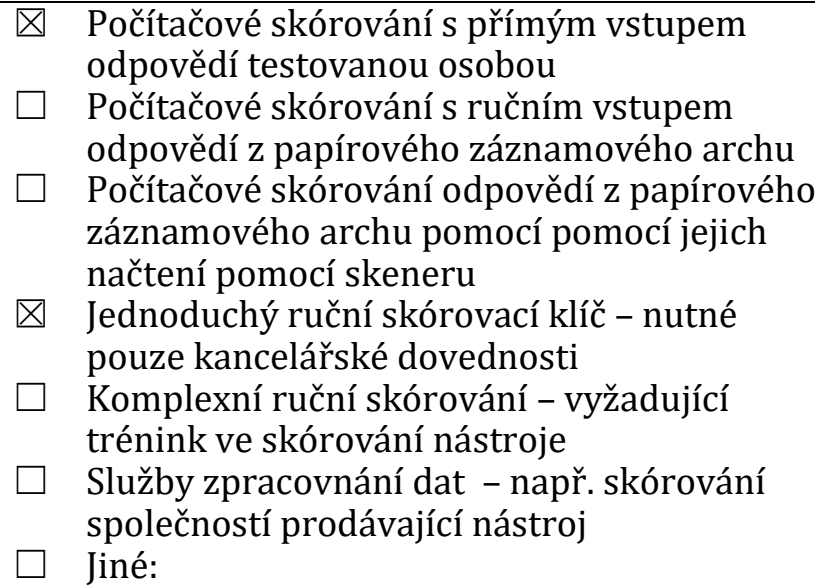 \\
\hline
\end{tabular}




\begin{tabular}{|c|c|c|}
\hline 1.18 & Skóry: & $\begin{array}{l}\text { Každá položka je hodnocena } 1 \text { (pro odpověd' } \\
\text { Nikdy) až } 3 \text { body (pro odpověd' Často). V obou } \\
\text { verzích lze spočítat hrubý skór jednak pro } \\
\text { jednotlivé klinické škály, dále pro dva dílčí } \\
\text { kompozitní indexy - Index regulace chování } \\
\text { (BRI; skládájící se z Inhibice, Přesunu pozornosti } \\
\text { a Emoční regulace) a Index metakognice (MI; } \\
\text { skládající se z Iniciativy, Pracovní paměti, } \\
\text { Plánování a organizace, Organizace pomůcek a } \\
\text { Kontroly chování) - a také celkový skór (Globální } \\
\text { exekutivní kompozit; GEC). Hrubý skór GEC je } \\
\text { možné vypočítat pouze tehdy, pokud schází méně } \\
\text { než } 14 \text { odpovědí na položky, které se podílí na } \\
\text { výpočtu celkového hrubého skóru. Současně } \\
\text { nesmí chybět více než dvě odpovědi při výpočtu } \\
\text { hrubého skóru pro konkrétní subškálu. V } \\
\text { případě, že daná odpověd' chybí, se automaticky } \\
\text { položka skóruje jako } 1 . \\
\\
\text { Pomocí normativních tabulek jsou poté hrubé } \\
\text { skóry jednotlivých subškál, dílčích indexů i } \\
\text { celkového skóre převedeny na T-skóry. Manuál } \\
\text { také uvádí } 90 \% \text { intervaly spolehlivosti a } \\
\text { percentily. Z T-skórů je poté vytvořen testový } \\
\text { profil dítěte. } \\
\text { Validizační škály zkoumají míru inkonzistence } \\
\text { respondenta a jeho negativitu. Skór ve Škále } \\
\text { inkonzistence je získán jako součet absolutních } \\
\text { rozdílı̊ mezi } 10 \text { dvojicemi položek s podobným } \\
\text { zněním. Skór menší nebo roven } 6 \text { je přijatelný a } \\
\text { skór větší nebo roven } 9 \text { indikuje } \\
\text { možné nevalidní odpovědi. Škála negativity se } \\
\text { skládá z devíti položek, u nichž byla ve } \\
\text { standardizační studii nízká četnost odpovědi } \\
\text { Často. Skór negativity je spočítán jako celkový } \\
\text { počet odpovědí Často na těchto devět položek. } \\
\text { Skór menší nebo roven } 4 \text { je považován za } \\
\text { přijatelný, naopak skór vyšší nebo roven } 7 \text { za } \\
\text { nápadně zvýšený. Nicméně vysoký skór } \\
\text { negativity může reflektovat i skutečně silné } \\
\text { narušení exekutivních funkcí dítěte. }\end{array}$ \\
\hline 1.19 & $\begin{array}{l}\text { Transformace skóru na standardní } \\
\text { skóry: }\end{array}$ & $\begin{array}{ll}\bigotimes & \text { Normalizovaná - skóry se získají použitím } \\
\text { normalizační tabulky } \\
\square \quad \text { Nenormalizovaná - skóry se získají lineární } \\
\text { transformací }\end{array}$ \\
\hline
\end{tabular}




\begin{tabular}{|c|c|c|}
\hline 1.20 & Použité škály & 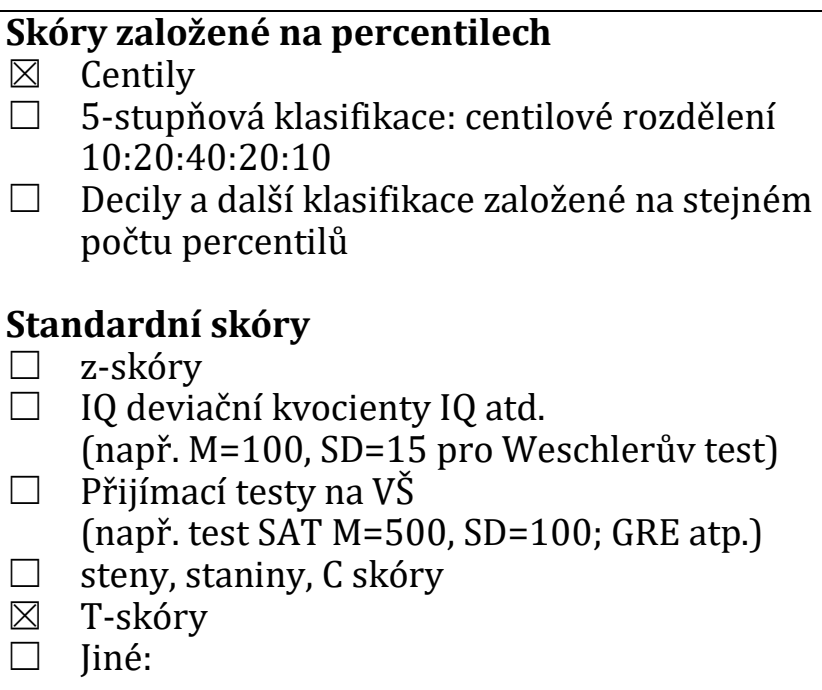 \\
\hline
\end{tabular}

\section{Část 4:}

Počítačově generované zprávy

Toto je čistě popisné. Hodnocení zpráv bude součástí části recenze nazvané Hodnocení.

\begin{tabular}{|l|l|ll|}
\hline 1.21 & $\begin{array}{l}\text { Jsou počítačově generované zprávy } \mathbf{k} \\
\text { dispozici s nástrojem? }\end{array}$ & $\bigotimes \quad$ Ano \\
& $\square \mathrm{Ne}$ \\
\hline
\end{tabular}

\begin{tabular}{|c|c|c|}
\hline 1.21 .0 & Název nebo popis zprávy: & $\begin{array}{l}\text { Zpráva BRIEF (verze pro rodiče i učitele jsou } \\
\text { srovnatelné) }\end{array}$ \\
\hline 1.21 .1 & $\begin{array}{l}\text { Média: } \\
\text { Zprávy mohou sestávat pouze z textu nebo obsahovat } \\
\text { text spolu s grafickými nebo tabulkovými zobrazeními } \\
\text { skórú (naprý. stenovými profily). Kde jsou prezentovány } \\
\text { text i data, mohou být prezentovány prostě paralelně, } \\
\text { nebo mohou být propojeny, takže vztah mezi textovými } \\
\text { výroky a skóry je explicitně vyjádřen. }\end{array}$ & $\begin{array}{ll}\square & \text { Pouze text } \\
\square & \text { Text a grafika bez vzájemného vztahu } \\
\bigotimes & \text { Integrovaný text a grafika }\end{array}$ \\
\hline 1.21 .2 & $\begin{array}{l}\text { Komplexnost: } \\
\text { Některé zprávy jsou velmi jednoduché, nap̌r. pouze } \\
\text { nahrazujíl kusem textu stenový skór v popisech } \\
\text { jednotlivých škál. Jiné jsou komplexnější, zahrnujíć ćásti } \\
\text { textu, které jsou ve vztahu ke vzorcům nebo } \\
\text { konfiguracím skóru škál a které berou v úvahu vliv } \\
\text { interakcí škál. }\end{array}$ & $\begin{array}{ll}\otimes & \text { Jednoduchá (Například seznam odstavců } \\
\text { podávajících popisy škál) } \\
\square & \begin{array}{l}\text { Střední (Směs jednoduchých popisů a } \\
\text { několika popisů konfigurací) }\end{array} \\
\square & \begin{array}{l}\text { Komplexní (Obsahuje popisy vzorců a } \\
\text { konfigurací skórů škál a interakce škál) }\end{array}\end{array}$ \\
\hline
\end{tabular}




\begin{tabular}{|c|c|c|}
\hline 1.21 .3 & $\begin{array}{l}\text { Struktura zprávy: } \\
\text { Struktura má vztah ke komplexitě. }\end{array}$ & 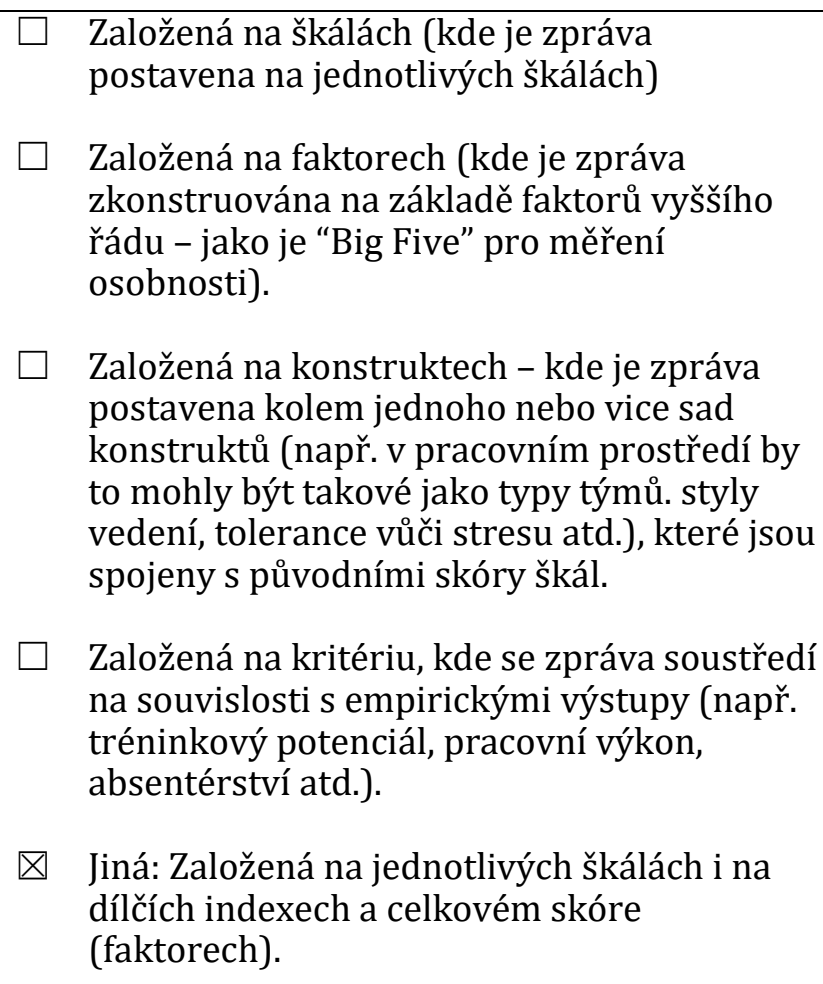 \\
\hline 1.21 .4 & 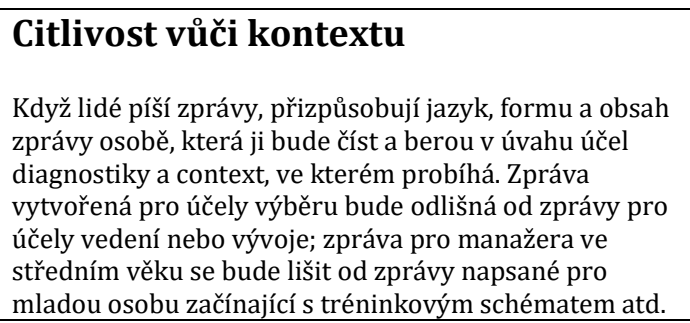 & $\begin{array}{l}\otimes \quad \text { Jedna verze pro všechny kontexty } \\
\square \quad \text { Předdefinované verze pro různé kontexty } \\
\square \quad \begin{array}{l}\text { Uživatelem definovatelné kontexty } \\
\text { a editovatelné zprávy }\end{array}\end{array}$ \\
\hline 1.21 .5 & $\begin{array}{l}\text { Klinická-pravděpodobnostní } \\
\text { Věť̌ina systémů zpráa je založena na klinickém úsudku. } \\
\text { To znamená, jeden nebo vice lidí, kteř́í jsou "expertní } \\
\text { uživatelé" daného nástroje, napsali části textu. Zprávy } \\
\text { tedy budou obsahovat jejich zvláštní interpretace škál. } \\
\text { Některé systémy obsahují pravděpodobnostní zprávy, } \\
\text { kde jou tvrzení založena na empirických validizačních } \\
\text { studích spojujících skóry škál např.s sírami pracovního } \\
\text { výkonu. }\end{array}$ & $\begin{array}{l}\square \quad \text { Založena na klinickém úsudku jednoho } \\
\text { experta } \\
\square \quad \begin{array}{l}\text { Založena na } \\
\text { empirických/pravděpodobnostních vztazích }\end{array} \\
\square \quad \begin{array}{l}\text { Založena na klinických úsudcích skupiny } \\
\text { expertů }\end{array}\end{array}$ \\
\hline 1.21 .6 & $\begin{array}{l}\text { Modifikovatelnost } \\
\text { Výstup zprávy je často fixní. Ale některé systémy vytvoří } \\
\text { výstup ve formě souboru, který mǔže uživatel dale } \\
\text { zpracovat. }\end{array}$ & $\begin{array}{ll}\bigotimes \quad \begin{array}{l}\text { Nemodifikovatelná (pouze fixní tištěný } \\
\text { výstup) }\end{array} \\
\square \quad \begin{array}{l}\text { Omezené modifikace (omezené na určité } \\
\text { oblasti, např. pole biografických dat) }\end{array} \\
\square \quad \begin{array}{l}\text { Neomezené modifikace (např. díky přístupu } \\
\text { k dokumentu ve Wordu) }\end{array}\end{array}$ \\
\hline 1.21 .7 & 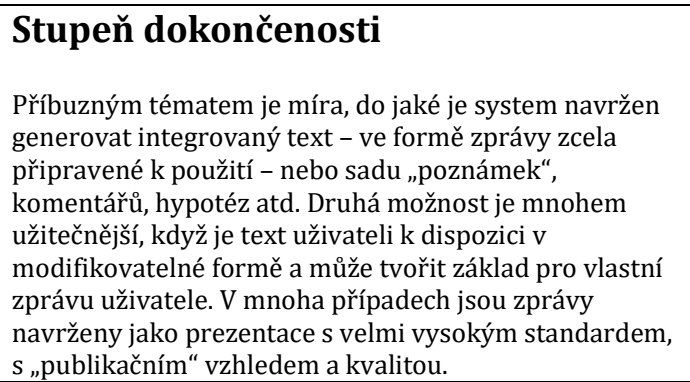 & $\begin{array}{ll}\square & \text { Publikační kvalita } \\
\bigotimes & \text { Kvalita pracovní verze }\end{array}$ \\
\hline
\end{tabular}




\begin{tabular}{|c|c|c|c|}
\hline 1.21 .8 & $\begin{array}{l}\text { Transparence } \\
\text { Systémy se liší svojí otevřeností nebo transparentností } \\
\text { vǔči uživateli. Otevřený system je ten, kde je spojení } \\
\text { mezi skórem škály a textem jasné a jednoznačné. Taková } \\
\text { otevřenost je možná pouze tehdy, když jsou } \\
\text { prezentovány jak texty, tak skóry, a spojení mezi nimi } \\
\text { explicitně uvedeno. Jiné systémy pracují jako "černé } \\
\text { skříňky" a znesnadňují uživateli dát do vztahu skóry škál } \\
\text { a text. }\end{array}$ & $\square$ & $\begin{array}{l}\text { Jasné spojení mezi skóry konstruktů } \\
\text { a textem } \\
\text { Zatajené spojení mezi konstrukty, skóry } \\
\text { a textem } \\
\text { Směs jasných/zatajených spojení mezi } \\
\text { konstrukty, skóry a textem }\end{array}$ \\
\hline 1.21 .9 & $\begin{array}{l}\text { Styl a tón } \\
\text { Systémy se take liší v míře, do jaké nabízejí čtenáři } \\
\text { zprávy vedení nebo smerr. Některé jsou deklarativní „Pan } \\
\text { X je velmi plachý a nebude dobrým prodejcem...“. Jiné } \\
\text { jsou navrženy tak, aby nabízely hypotézy nebo vznášely } \\
\text { otázky: „Na základě jeho skórủ na škále Y se pan X zdá } \\
\text { být velmi plachým. Pokud je to tak, mohlo by pro něho } \\
\text { být obtížné pracovat v prostředí prodeje. Je nutné to } \\
\text { v jeho případě dale prozkoumat.” }\end{array}$ & $\begin{array}{l}\square \\
\square \\
\square\end{array}$ & $\begin{array}{l}\text { Direktivní } \\
\text { Hypotetizující } \\
\text { Jiné: }\end{array}$ \\
\hline 1.21 .10 & Zamýšlení příjemci & $\begin{array}{l}\square \\
\square\end{array}$ & $\begin{array}{l}\text { Kvalifikovaní uživatelé testu } \\
\text { Osoby kompetentní vytvořit vlastní zprávy. } \\
\text { Kvalifikovaní uživatelé systému } \\
\text { Osoby, které nejsou kompetentní vytvořit samostatně } \\
\text { vlastní zprávy, ale mají trénink potřebný pro používání } \\
\text { zpráv generovaných systémem. } \\
\text { Respondenti testu } \\
\text { Respondent testu zpravidla nemá žádnou předchozí } \\
\text { znalost nástroje ani typu zprávy. } \\
\text { Třetí strany } \\
\text { Např. potenciální zaměstnavatel, rodič vedoucí či } \\
\text { supervizor apod. }\end{array}$ \\
\hline 1.22 & $\begin{array}{l}\text { Nabízejí distributoři službu opravy } \\
\text { a/nebo vývoje počítačových zpráv? }\end{array}$ & $凶$ & $\begin{array}{l}\text { Ano } \\
\mathrm{Ne}\end{array}$ \\
\hline
\end{tabular}

Č́ást 5:

Nabídka, podmínky a náklady

Tato část definuje, co vydavatel poskytne, komu, za jakých podmínek a za jaké ceny. Definuje podmínky kladené dodavatelem a týkající se toho, kdo smí a kdo nesmí získat materiál nástroje. Pokud jedna z možností neodpovídá podmínkám nabídky, doplňte popis relevantních podmínek.

\begin{tabular}{|c|c|c|}
\hline 1.23 & $\begin{array}{l}\text { Dokumentace poskytovaná } \\
\text { distributorem jako součást } \\
\text { testového balíku }\end{array}$ & 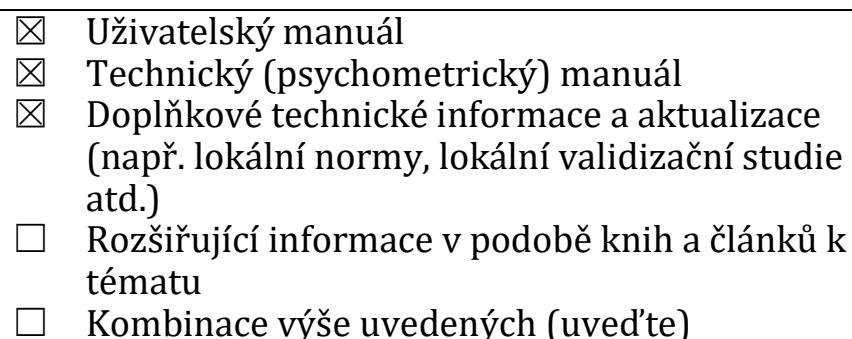 \\
\hline
\end{tabular}




\begin{tabular}{|c|c|c|}
\hline 1.24 & Metody publikace & $\begin{array}{ll}\bigotimes & \text { Papír } \\
\square & \text { PC - Diskety } \\
\square & \text { PC - CD/ROM } \\
\square & \text { Download z internetu } \\
\square & \text { Živý internet (nástroj pracuje v internetovém } \\
& \text { prohlížeči) } \\
\square & \text { Jiné: }\end{array}$ \\
\hline 1.25 .1 & $\begin{array}{l}\text { Počáteční náklady. } \\
\text { Cena kompletní sady materiálů (všechny manuály a } \\
\text { dalšś material nutný k aspoñ jedné zkušební } \\
\text { administraci). Kolik uchazečú lze vyšetřovat pomocí } \\
\text { materiálu získaných za počátečń náklady, kde tyto } \\
\text { náklady zahrnují materially pro opakované vyšstř̌ení. }\end{array}$ & $\begin{array}{l}\text { Úplný testový soubor (papírová verze; zahrnuje } \\
\text { manuál, } 30 \text { ks dotazníků pro rodiče, } 30 \text { ks dotazníků } \\
\text { pro učitele, } 30 \text { vyhodnocovacích listů verze pro } \\
\text { rodiče, } 30 \text { vyhodnocovacích listů verze pro učitele): } \\
2990 \text { Kč } \\
\text { Možnost zakoupení samostatné příručky ( } 850 \text { Kč) a } \\
\text { administrace v systém HTS } 5 \text { (základní ročnílicence } \\
1600 \text { Kč) a dokupování kreditů v závislosti na } \\
\text { množství se cena pohybuje od } 30 \text { Kč (při nákupu } \\
200 \text { a více kreditů) do } 165 \text { Kč (při nákupu } 1 \text { až } 9 \\
\text { kreditů) za } 1 \text { kredit (tj. } 1 \text { vyšetření). Př́padně je } \\
\text { možné zakoupit jednorázové online testování za } \\
200 \text { Kč. }\end{array}$ \\
\hline 1.25 .2 & Opakující se náklady: & $\begin{array}{l}\text { Papírová verze: } \\
\text { Dotazník verze pro rodiče, } 30 \text { ks: } 900 \text { Kč } \\
\text { Dotazník verze pro učitele, } 30 \text { ks: } 900 \text { Kč } \\
\text { Vyhodnocovací list verze pro rodiče, } 30 \text { ks: } 200 \text { Kč } \\
\text { Vyhodnocovacíl list verze pro učitele, } 30 \text { ks: } 200 \text { Kč } \\
\text { Počítačová verze: } \\
\text { Dokupování kreditů. V závislosti na množství se } \\
\text { cena pohybuje od } 30 \text { Kč (při nákupi } 200 \text { a více } \\
\text { kreditů) do } 165 \text { Kč (při nákupu } 1 \text { až } 9 \text { kreditů) na } 1 \\
\text { kredit. Př́́padně je možné zakoupit jednorázové } \\
\text { online testování za } 200 \text { Kč. }\end{array}$ \\
\hline 1.26 .1 & $\begin{array}{l}\text { Ceny za zprávy generované } \\
\text { softwarem nainstalovaným } \\
\text { uživatelem: }\end{array}$ & - \\
\hline 1.26 .2 & $\begin{array}{l}\text { Ceny za vyhotovení zprávy zaslené } \\
\text { prostřednictvím pošty/faxu: }\end{array}$ & - \\
\hline 1.26 .3 & $\begin{array}{l}\text { Ceny za vyhotovení zprávy zaslené } \\
\text { prostřednictvím internetové služby: }\end{array}$ & - \\
\hline 1.27 & $\begin{array}{l}\text { Ceny za další služby a zpracování } \\
\text { dat: opravy nebo vývoj } \\
\text { automatických zpráv: }\end{array}$ & - \\
\hline
\end{tabular}




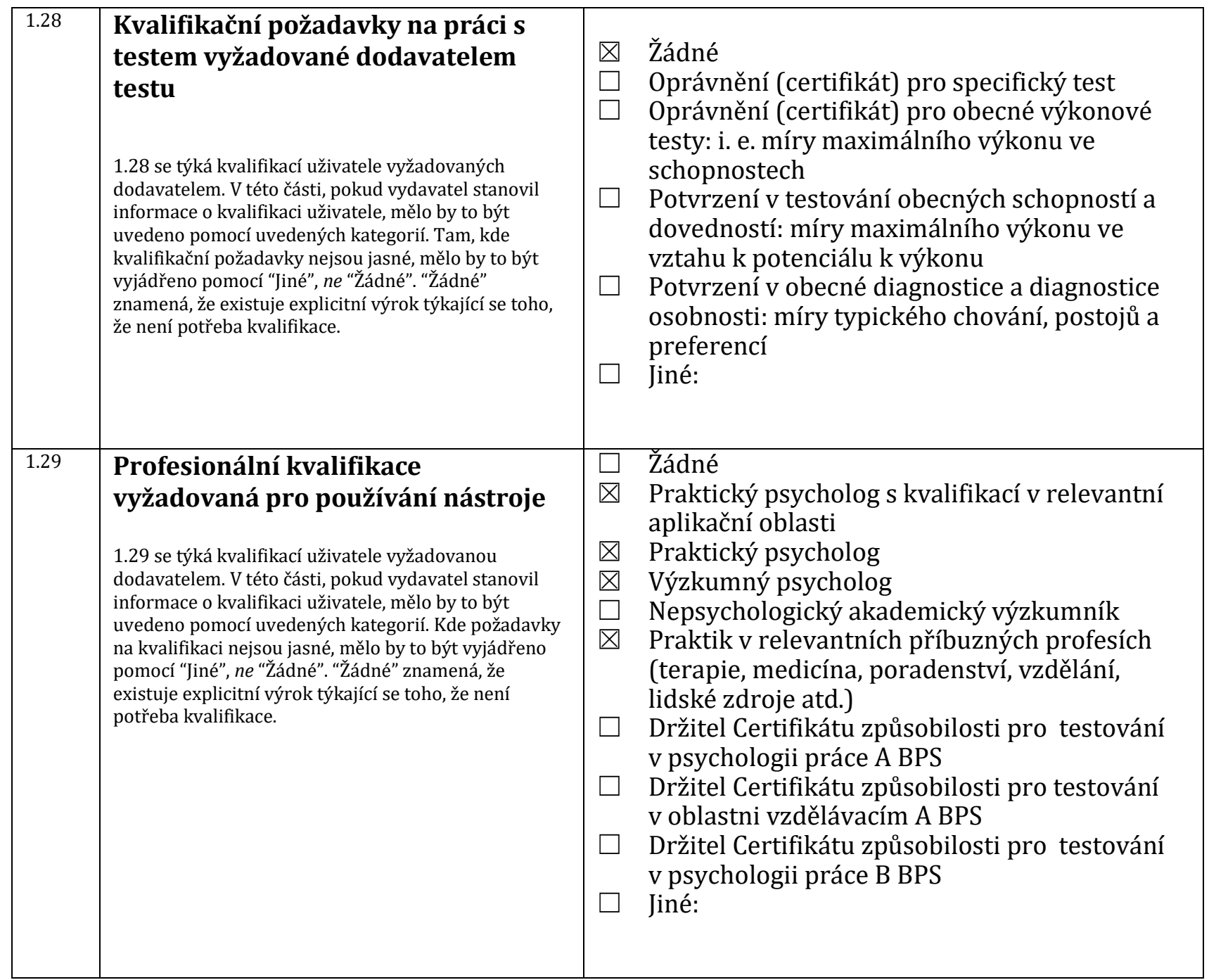

\section{Č́st 6:}

\section{Hodnocení testových materiálů}

\section{Vysvětlení hodnocení}

V následujících částech jsou celková posouzení adekvátnosti informací týkajících se validity, reliability a norem zobrazeny automaticky tučně.

Jakýkoli nástroj s jedním nebo více posouzeními 0 nebo 2 týkajícími se atributů považovaných za kritické pro bezpečné používání nástroje, by neměl být považován za nástroj, který splňuje minimální standardy. 


\begin{tabular}{|c|c|c|c|}
\hline $\begin{array}{l}\text { Vstup na posuzovacím } \\
\text { formuláři }\end{array}$ & $\begin{array}{l}\text { Posouzení podle } \\
\text { standardi̊ EFPA }\end{array}$ & $\begin{array}{c}\text { Reprezentace recenze } v \\
\mathrm{UK}\end{array}$ & Vysvětlení \\
\hline [n/a] & [n/a ] & [n/a ] & $\begin{array}{l}\text { Tento atribut není u tohoto } \\
\text { nástroje použitelný }\end{array}$ \\
\hline $\mathbf{0}$ & {$[-]$} & [None ] & $\begin{array}{l}\text { Není možné posoudit jako } \\
\text { ne nebo nedostatek } \\
\text { poskytnutých informací }\end{array}$ \\
\hline 1 & {$[-1]$} & {$\left[\begin{array}{ll}* & ]\end{array}\right.$} & Neadekvátní \\
\hline 2 & & {$\left[\begin{array}{ll}* * & ]\end{array}\right.$} & NYNÍ NEPOUŽÍVÁNO \\
\hline 3 & {$\left[\begin{array}{ll}0 & 0\end{array}\right]$} & {$[* * *]$} & Adekvátní nebo přiměřený \\
\hline 4 & [ 1 ] & {$[* * * *]$} & Dobrý \\
\hline \multirow[t]{2}{*}{5} & [ 2 ] & {$[* * * * *]$} & Vynikající \\
\hline & & $\begin{array}{l}\text { [N.r.i.o.r] }{ }^{*} \text { (pouze pro } \\
\text { aktualizace) }\end{array}$ & $\begin{array}{l}\text { Položka nebyla v původní } \\
\text { recenzi posuzována }\end{array}$ \\
\hline
\end{tabular}

V této části má být provedeno více hodnocení různých aspektů nebo atributů dokumentace dodávané s nástrojem (nebo balíkem). Termín „dokumentace“ byl vybrán, aby pokrýval všechny ty materiály dodávané s nástrojem nebo snadno dostupné kvalifikovanému uživateli: např. manual administrátora; technické př́ručky; brožury s normami; dodatky k manuálu; aktualizace od vydavatelů/dodavatelů atd.

Položky mají být posuzovány n/a nebo 0 až 5 (poloviční rating je přijatelný)

Rating

\begin{tabular}{|c|c|c|}
\hline \multicolumn{2}{|c|}{$\begin{array}{l}\text { Kvalita vysvětlení principů, prezentace a kvalita poskytnuté informace: } \\
\text { (Tento celkový rating se získá použitím posouzení založeného na ratinzích daných pro položky 2.1-2.8) }\end{array}$} & \multirow{2}{*}{1,5} \\
\hline 2.1 & $\begin{array}{l}\text { Celkový rating kvality vysvětlení principů: (Tento celkový rating se získá použitím } \\
\text { posouzení založeného na hodnotách ratingů daných pro položky } 2.1 .1-2.1 .5 \text { ) }\end{array}$ & \\
\hline 2.1 .1 & i) Teoretické základy konstruktů: & 1,5 \\
\hline 2.1 .2 & ii) Procedura vývoje testu: & 1,5 \\
\hline 2.1 .3 & iii) Důkladnost analýz položek a model analýzy položek: & 1,5 \\
\hline 2.1 .4 & iv) Vysvětlení obsahové validity: & 1,5 \\
\hline 2.1 .5 & v) Souhrn relevantního výzkumu: & 3 \\
\hline 2.2 & $\begin{array}{l}\text { Adekvátnost dokumentace dostupné uživateli (uživatelské a technické } \\
\text { manuály, dodatky týkající se norem atd.): (Tento celkový rating se získá použitím } \\
\text { posouzení založeného na hodnotách ratingů daných pro položky } 2.2 .1-2.2 .6 \text { ) } \\
\text { Pro část } 2.2 \text { jsou stanoveny následující „měřítka“ pro rating „vynikající“ (5). Pozornost je zde zaměřena } \\
\text { na kvalitu pokrytí poskytnutého v dokumentaci dostupné kvalifikovaným uživatelům. Všimněte si, že část } \\
2.2 \text { se týká úplnosti a jasnosti dokumentace dostupné uživateli (uživatelské a technické manually, doadtky } \\
\text { k normám atd.) v pojmech pokrytí a vysvětlení. V pojmech kvality nástroje, jak ji dosvědčuje dokumentace, } \\
\text { jsou rozpracovány oblasti v této části pod čísly: } 2.1,2.3,2.9,2.10 \text { a } 2.11 \text {. }\end{array}$ & 1,5 \\
\hline 2.2 .1 & $\begin{array}{l}\text { Principy: [viz 2.1] } \\
\text { Dobře argumentovaný a jasně prezentovaný popis toho, co má podle návrhu měřit a proč byl zkonstruován } \\
\text { tak, jak je. }\end{array}$ & 1,5 \\
\hline 2.2 .2 & $\begin{array}{l}\text { Vývoj: } \\
\text { Úplné detaily týkající se zdrojů položek, pilotáže, analýz položek, srovnávacích studií a změn prováděných v } \\
\text { prủběhu vývojovyych pokusủ. }\end{array}$ & 1 \\
\hline 2.2 .3 & $\begin{array}{l}\text { Standardizace: } \\
\text { Jasné a detailní informace poskytnuté o velikostech a zdrojích standardizačního souboru a standardizační } \\
\text { proceduře. }\end{array}$ & 3 \\
\hline 2.2 .4 & $\begin{array}{l}\text { Normy: } \\
\text { Jasné a detailní informace poskytnuté o velikostech a zdrojích normalizačních skupin, podmínkách vyšetření } \\
\text { atd. }\end{array}$ & 3 \\
\hline 2.2 .5 & $\begin{array}{l}\text { Reliabilita: } \\
\text { Dobré vysvětlení reliability a široký rozsah měr vnitřní konsistence a retestu spolu s vysvětlením jejich } \\
\text { relevance a zobecnitelnosti nástroje vyšetření. }\end{array}$ & 3 \\
\hline 2.2 .6 & $\begin{array}{l}\text { Validita: } \\
\text { Dobré vysvětlení validity spolu s širokou škálou studií jasně a poctivě popsaných. }\end{array}$ & 1,5 \\
\hline
\end{tabular}




\begin{tabular}{|c|c|c|}
\hline 2.3 & $\begin{array}{l}\text { Kvalita procedurálních instrukcí poskytnutých uživateli: (Tento celkový rating se } \\
\text { získá s použitím posouzení na základě hodnot ratingů daných pro položky } 2.3 .1-2.3 .7 \text { ) }\end{array}$ & 3 \\
\hline 2.3 .1 & $\begin{array}{l}\text { Pro administraci testu: } \\
\text { Poskytnutá jasná a detailní vysvětlení a procedurální průvodce krok za krokem spolu s dobrými radami } \\
\text { týkajícícmi se otázek uchazeču a problémových situací. }\end{array}$ & 3,5 \\
\hline 2.3 .2 & $\begin{array}{l}\text { Pro skórování testu, normy atd.: } \\
\text { Poskytnuté jasné a detailní informace spolu s popsanými kontrolami pro vyhnutí se možným chybám } \\
\text { skórování. }\end{array}$ & 4 \\
\hline 2.3 .3 & $\begin{array}{l}\text { Pro interpretaci a vytváření zpráv: } \\
\text { Detailní doporučení týkající se interpretace různých skórů, chápání normativních měr a zacházení se vztahy } \\
\text { mezi různými škálami, s množstvím ilustrativních př́ikladú a př́ipadových studií. }\end{array}$ & 3,5 \\
\hline 2.3 .4 & $\begin{array}{l}\text { Pro poskytnutí zpětné vazby a debriefingu respondentům testu a dalším: } \\
\text { Detailní doporučení, jak prezentovat zpětnou vazbu uchazečum. }\end{array}$ & 0 \\
\hline 2.3 .5 & $\begin{array}{l}\text { Pro poskytování dobrých praktických témat týkajících se poctivosti a } \\
\text { zkreslení: } \\
\text { Uvedení detailních informací o studiích sexuálního a etnického zkreslení s relevantními varováními týkajícími } \\
\text { se používání a zobecňování validit. }\end{array}$ & 1 \\
\hline 2.3 .6 & $\begin{array}{l}\text { Omezení používání: } \\
\text { Jasné popisy, kdo by měl a kdo by neměl být vyšetřován spolu s dobře vysvětlenými odůvodněními těchto } \\
\text { omezení (např. typy nezpůsobilostí, požadované úrovně gramotnosti atd.). }\end{array}$ & 1 \\
\hline 2.3 .7 & $\begin{array}{l}\text { Reference a podpůrné materiály: } \\
\text { Detailní odkazy na relevantní podpůrnou akademickou literature a křížové odkazy na další př́ibuzné } \\
\text { materially týkající se diagnostických nástrojü. }\end{array}$ & 3 \\
\hline \multicolumn{2}{|c|}{$\begin{array}{l}\text { Kvalita materiálů: } \\
\text { (Tento celkový rating se získá použitím posouzení založeného na hodnotách ratingů pro položky } 2.4-2.8 \text { ) }\end{array}$} & 3 \\
\hline 2.4 & $\begin{array}{l}\text { Všeobecná kvalita materiálů testu } \\
\text { (testové brožury, odpověd'ové archy, testové objekty, software atd.): }\end{array}$ & 3 \\
\hline 2.5 & Kvalita lokální adaptace testu (pokud byl test přeložen a adaptován do místního jazyka): & 1,5 \\
\hline 2.6 & Snadnost, s jakou může respondent testu porozumět úkolu: & 4 \\
\hline 2.7 & $\begin{array}{l}\text { Snadnost, s jakou mohou být respondentem testu tvořeny reakce nebo } \\
\text { odpovědi: }\end{array}$ & 5 \\
\hline 2.8 & Kvalita položek: & 3 \\
\hline
\end{tabular}

Dokumentace, ačkoliv poměrně rozsáhlá, úplně postrádá nebo specifikuje pouze povrchně několik důležitých informací. $V$ první řadě teoretické východisko dle našeho názoru není dostatečně rozvedeno a vztaženo na testovou metodu a všechny její škály. Manuál pouze velmi povrchně popisuje fungování exekutivních funkcí a krátce nastiňuje různé přístupy k exekutivním funkcím bez bližšího vztažení $\mathrm{k}$ tomu, jak přesně $\mathrm{z}$ nich bylo při vývoji testu vycházeno. Také chybí informace o tom, jak byli vybíráni experti a lidé z praxe, kteří měli poskytnout př́klady typického chování, které může indikovat narušení fungování exekutivních funkcí a ze kterého bylo při vývoji položek vycházeno. Velkou slabinu popisu vývoje metody poté představuje zmatečné vysvětlení způsobu zařazení položek do té které škály a ověření této struktury. Z popisu explorační faktorové analýzy není jasné, jak přesně autoři postupovali, ani nejsou poskytnuty bližší informace o analýze. Současně zcela chybí ověření struktury modelu pomocí konfirmační analýzy na větším souboru (více viz Část 7: Validita).

Co se týče samotného vyznění položek, dle našeho pohledu neobsahují žádné významné nejasnosti. Položky jsou formulovány srozumitelně a obtížností na pochopení dle manuálu odpovídají úrovni vzdělání 4 . až 5 . třídy. Nicméně některé položky mohou být problematické svou formulací nebo i samotným obsahem. Např́klad některé položky se dotazují na dvě věci zároveň (např̀. „Nedostatečně si uvědomuje své přednosti a slabosti“) nebo jsou formulovány záporně a odpovídání na škále NikdyObčas-Často může pro respondenta být náročnější. Dále se domníváme, že některé položky mohou být již irelevantní pro určité skupiny. Např. položka, která se dotazuje na neuklízení hraček, je pro adolescenta nevhodná. Současně položky často vyžadují poměrně detailní představu o fungování dítěte $\mathrm{v}$ různých kontextech, kterou rodič adolescenta již nemusí mít, a jeho odpovědi tak mohou být zkreslené. Položky také mohou fungovat různě nejen na základě věku ale i jiných kategorií (pohlaví, SES, etnikum apod.). Například položka „Má potíže s dokončením úkolu“ může být problematická 
$\mathrm{v}$ případě, že dítě žije $\mathrm{v}$ přeplněném, neklidném prostředí a nemá tak vhodné podmínky $\mathrm{k}$ tomu úkol dokončit. $\mathrm{V}$ tomto kontextu považujeme za problematické, že se při vývoji testu tento aspekt nezohlednil a není k dispozici DIF analýza nebo invariance pro různé skupiny.

Ve verzi papír tužka je záznamový arch tvořen propisovacím papírem, po jehož odstranění uživatel testu získá formulář, který usnadňuje vyhodnocení. Instrukce $\mathrm{k}$ administraci testu manuál popisuje dostatečně, včetně toho, jak rodiče/učitele namotivovat (vysvětlení testování, zdůraznění zájmu dítěte). Nicméně neobsahuje rady, jak reagovat na možné dotazy respondenta nebo jiné problematické situace, které mohou vyvstat. $\mathrm{V}$ počítačové verzi mají materiály následující problémy: 1) Na začátku při vyplňování osobních údajů nelze poznat, zdali mají být vyplněny údaje respondenta nebo dítěte. To je problematické hlavně kvưli věku, na základě kterého se ve zprávě interpretují skóry vzhledem k normám. Chybné uvedení věku dospělého místo dítěte zprávu zkreslí. 2) Zatímco manuál poskytuje pro verzi papír-tužka instrukce jak rodiče/učitele namotivovat ke spolupráci, tento úvod v počítačové verzi chybí. 3) V instrukcích, které respondent uvidí, se uvádí, že každou svou odpověd' má potvrdit. Nicméně se nepíše, že tak učiní druhým pokliknutím na zvolenou možnost, což může v první chvíli na respondenta působit zmatečně. Jako pozitivum ale vnímáme to, že systém upozorní respondenta, pokud odpovídá moc rychle (a poprosí ho, aby se nad položkou zamyslel), nebo moc pomalu. Nicméně u pomalé odpovědi doplňuje prosbu o rychlejší odpověd' tím, že jsou důležité spontánní reakce. Taková informace by měla být uvedena i v samotném úvodu s instrukcemi.

\section{Č́st 7:}

\section{Hodnocení norem, reliability a validity}

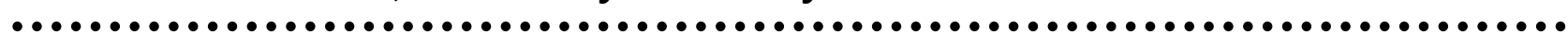

\section{Informace o normách nebo referenční skupině}

\begin{tabular}{|c|c|c|}
\hline 2.9 & Celková adekvátnost: & 1 \\
\hline 2.9 .1 & 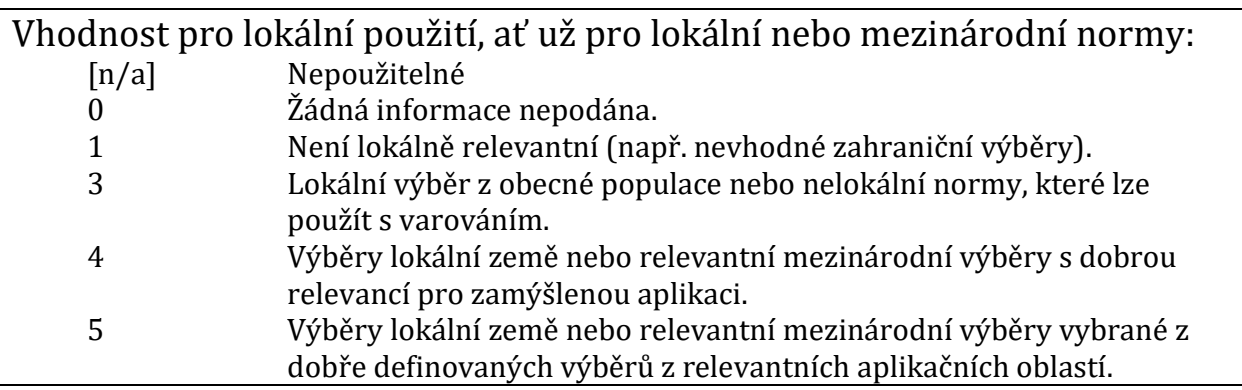 & 1 \\
\hline 2.9 .2 & $\begin{array}{ll}\begin{array}{l}\text { Vhodnost pro zamýšlené aplikace: } \\
{[\mathrm{n} / \mathrm{a}]}\end{array} & \text { Nepoužitelné } \\
0 & \text { Žádná informace nepodána. } \\
1 & \text { Norma nebo normy nejsou adekvátní pro zamýšlené aplikace. } \\
3 & \text { Adekvátní normy pro obecnou populaci a/nebo rozmezí normativních } \\
& \text { tabulek. } \\
4 & \text { Dobré rozmezí normativních tabulek. } \\
5 & \begin{array}{l}\text { Vynikající rozmezí výběrově relevantních norem vztahujících se k věku } \\
\text { a pohlaví, s informacemi o dalších rozdílech v rámci skupin (např. } \\
\end{array}\end{array}$ & 1 \\
\hline
\end{tabular}




\begin{tabular}{|c|c|c|c|}
\hline 2.9 .3 & $\begin{array}{l}\text { Velikosti výběrů: } \\
\text { [n/a] } \\
0 \\
1 \\
3 \\
4 \\
5 \\
\end{array}$ & $\begin{array}{l}\text { : } \\
\text { Nepoužitelné } \\
\text { Žádná informace nepodána. } \\
\text { Neadekvátní výběry (např. méně než 150). } \\
\text { Adekvátní výběry (např. 150-300). } \\
\text { Velké výběry (např. 300-1000). } \\
\text { Velmi velké výběry (např. 1000+). }\end{array}$ & $\begin{array}{c}3 \text { (rodiče); } 1 \\
\text { (učitelé) }\end{array}$ \\
\hline 2.9 .4 & $\begin{array}{c}\text { Procedury použi } \\
\text { (vyberte jednu a ohoc } \\
\square \\
\square \\
\square \\
\square\end{array}$ & $\begin{array}{l}\text { ité při výběru souboru: } \\
\text { dnot'te kvalitu použitého postupu) } \\
\text { Žádná informace neposkytnuta } \\
\text { Reprezentativní populaci [sumarizujte kritéria] } \\
\text { Nahodilá } \\
\text { Náhodná }\end{array}$ & 3 \\
\hline 2.9 .5 & $\begin{array}{l}\text { Kvalita informac } \\
\text { vlivech věku, rod } \\
\text { [n/a] } \\
0 \\
1 \\
3 \\
4 \\
5\end{array}$ & $\begin{array}{l}\text { :í poskytnutých o minoritní/chráněné skupině, rozdílech, } \\
\text { du atd.: } \\
\text { Nepoužitelné } \\
\text { Žádná informace nepodána. } \\
\text { Neadekvátní informace. } \\
\text { Adekvátní obecné informace s minimální analýzou. } \\
\text { Dobré popisy a analýzy skupin a rozdílů } \\
\text { Vynikající série analýz a diskuse o relevantních tématech vztahujících } \\
\text { se k použití a interpretaci. }\end{array}$ & 3 \\
\hline
\end{tabular}

2.9.6 Komentáře recenzentů k normám: Stručná zpráva o normách a jejich historii, včetně informací o doporučeních učiněných vydavatelem/autorem pro aktualizaci norem obvyklým způsobem.

České normy metody BRIEF nejsou dostupné. V rámci české standardizační studie $\left(N_{\text {rodice }}=358, N_{\text {ữelel }}=\right.$ 358) byly pro srovnání s americkými normami pouze spočítány rozdíly hrubých skórů jednotlivých škál mezi českým a americkým vzorkem. Reportovány jsou tyto rozdíly ale pouze pro jednotlivé věkové kategorie u dívek, nikoli u chlapců.

Autoři české standardizace doporučují pracovat s americkými normami, pro což argumentují především malými rozdíly ve skórech jednotlivých škál mezi jednotlivými věkovými kategoriemi českého standardizačního a amerického normativního vzorku. Absolutní rozdíly v průměrných hrubých skórech mezi českým a americkým souborem se v jednotlivých škálách i indexech pohybují od 0 do 5,83 ve verzi pro rodiče, resp. 0,02 až 4,97 ve verzi pro učitele. Autoři argumentují hlavně nesignifikancí na $5 \%$ hladině významnosti u většiny z nich. Velikosti účinku těchto rozdílů se po dopočítání pohybují v rozmezí $0<$ Cohenovo $d<0,57$ (medián 0,2 ). Např́klad u škály Iniciativa ve verzi pro rodiče je pro jednotlivé věkové skupiny medián Cohenova $d$ roven 0,5 . V př́padě verze pro učitele se nám srovnávání nicméně jeví jako nevhodné, protože věkové kategorie, s nimiž pracovali autoři české standardizace, se plně nepřekrývají s věkovými kategoriemi v americké standardizaci (např. kategorie 8-10 let v české verzi vs. kategorie 7-8 v americké). $V$ př́ípadě jediného smysluplného porovnání (věková skupina 14-18 let) medián Cohenova $d$ dosahuje 0,29 a u čtyř škál je velikost účinku středně silná až silná $(0,46<$ Cohenovo $d<0,52)$. Odhlédneme-li od toho, že je porovnávání odlišných věkových skupin ve verzi pro učitele samo o sobě problematické, lze konstatovat, že v obou verzích uvedené velikosti rozdílů přinejmenším v některých subškálách nejsou zanedbatelné a mohou poukazovat na jejich odlišné fungování v českém prostředí, které by bylo vhodné ověřit.

Nad rámec výše uvedeného autoři české standardizace argumentují údajnou empiricky prokázanou nezávislostí výsledků na sociokulturním prostředí. Argumentace autorů se nám ale celkově jeví jako nedostatečná. Především nejsou poskytnuty žádné důkazy o ekvivalenci měření (invarianci) české a anglické verze dotazníku. Nelze proto posoudit, zda BRIEF měří v českých podmínkách ty stejné zamýšlené konstrukty. Americký normativní vzorek byl vybrán, aby reflektoval rozložení klíčových demografických charakteristik (pohlaví, socioekonomický status (SES), etnikum, věk, hustota osídlení) populace USA, nikoli České republiky. Konkrétní informace o složení normativního vzorku jsou navíc podány pouze s ohledem na pohlaví a věk hodnocených dětí. Není jasné, jaké bylo rozložení dalších charakteristik, a proto není možné zhodnotit, zda alespoň přibližně odráží specifika české populace. Uvedené skutečnosti chápeme jako o to problematičtější, že americké normy byly vytvářeny okolo roku 2000. Pro aktuální použití se tak jeví jako potenciálně zastaralé. Krom výše uvedeného 
navíc autoři americké standardizace zmiňují negativní korelaci skórů ve většině klinických škál jednak se SES, jednak se vzděláním rodičů - děti z rodin s nižším SES a děti rodičů s nižším dosaženým vzděláním tak byly $\mathrm{v}$ průměru hodnoceny hůře. To samo o sobě nepoukazuje na sociokulturní podmíněnost výsledků BRIEF, aby ale bylo možné konstatovat jejich sociokulturní nezávislost, bylo by alespoň pro uvedené demografické charakteristiky vhodné ověřit invarianci měření potažmo diferenciální fungování položek BRIEF.

Americký normativní vzorek $\left(N_{\text {rodice }}=1419, N_{\text {ututele }}=720\right)$ byl získán na 25 školách v americkém státu Maryland. Normy jsou kvůli zjištěným rozdílům skórů škál BRIEF mezi pohlavími a věkovými kategoriemi rozčleněny do celkem 16 normativních tabulek podle verze (rodiče x učitelé), pohlaví a věku (verze pro rodiče: 5-7, 8-10, 11-13 a 14-18 let; verze pro učitele: 5-6, 7-8, 9-13 a 14-18 let). V př́padě verze pro rodiče jsou velikosti výběrů adekvátní $(N=144-167$ pro jednotlivé věkové kategorie chlapců, $N=161-262$ pro jednotlivé věkové kategorie dívek). V př́padě verze pro učitele jsou ovšem ve většině kategorií nedostačující (ve věkových skupinách 5-6 a 7-8 u chlapců a 5-6 u dívek $N<50$, ve věkových skupinách 7-8 u chlapců a 7-8 a 14-18 u dívek $N<100$, pouze ve věkové skupině $9-13$ u chlapců $N=162$ a věkové skupině $9-13$ u dívek $N=224$ ).

\section{Validita}

\begin{tabular}{|c|c|c|}
\hline 2.10 & $\begin{array}{l}\text { Celková adekvátnost: (Tento celkový rating se získá na základě posouzení hodnot ratingů } \\
\text { daných v položkách } 2.10 .1-2.10 .2 .4 \text {. Neprůměrujte pouze čísla, abyste získali celkový rating. } \\
\text { Obvykle bude roven bud' konstruktové validitě nebo validitě vztahující se ke kritériu, podle } \\
\text { toho, která z nich je vyšší.) }\end{array}$ & 1 \\
\hline 2.10 .1 & $\begin{array}{l}\text { Konstruktová validita - celková adekvátnost } \\
\text { (Tento celkový rating se získá na základě posouzení hodnot ratingů daných v položkách } \\
2.10 .1 .2-2.10 .1 .6 \text {. Neprůměrujte pouze čísla, abyste tento celkový rating získali.) }\end{array}$ & 1 \\
\hline 2.10 .1 .1 & \multicolumn{2}{|c|}{ 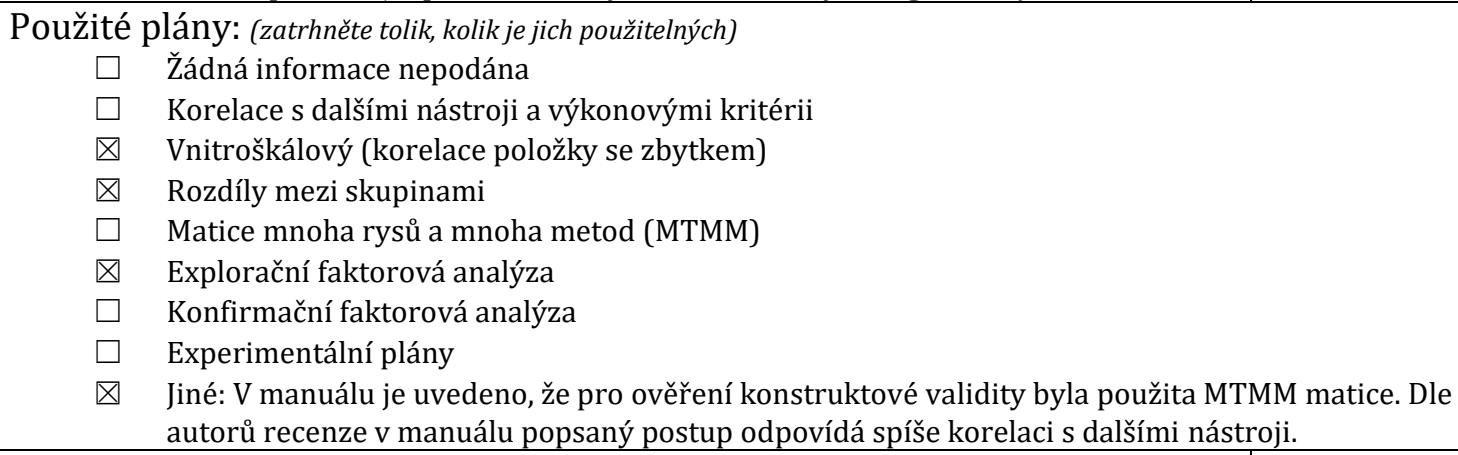 } \\
\hline 2.10 .1 .2 & $\begin{array}{cl}\text { Velikosti výběrů: } & \\
0 & \text { Žádná informace neposkytnuta. } \\
1 & \text { Jedna neadekvátní studie (např. velikost výběru menší než 100). } \\
3 & \text { Jedna adekvátní studie (např. velikost výběru 100-200). } \\
4 & \text { Více než jedna adekvátní nebo velká studie. } \\
5 & \text { Dobrá série adekvátních až rozsáhlých studií. }\end{array}$ & 4 \\
\hline 2.10 .1 .3 & \multicolumn{2}{|l|}{ 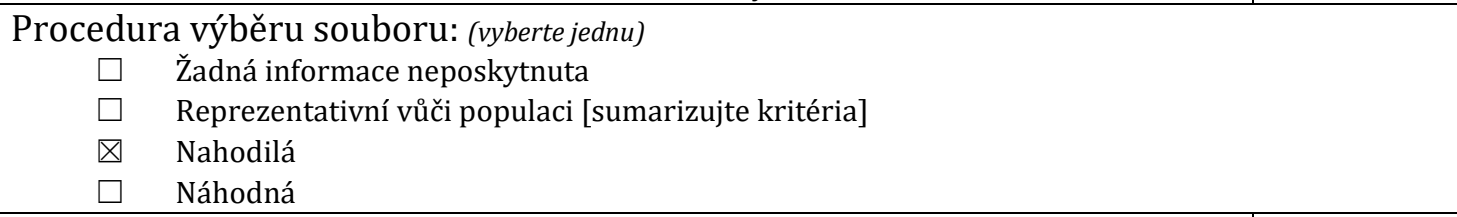 } \\
\hline 2.10 .1 .4 & $\begin{array}{cl}\text { Medián a rozsah korelací mezi testem a dalšími podobnými testy: } \\
0 & \text { Žádná informace neposkytnuta. } \\
1 & \text { Neadekvátní }(\mathrm{r}<0.55) . \\
3 & \text { Adekvátní }(0.55<\mathrm{r}<0.65) . \\
4 & \text { Dobrý }(0.65<\mathrm{r}<0.75) . \\
5 & \text { Vynikající }(\mathrm{r}>0.75)\end{array}$ & 3 \\
\hline
\end{tabular}




\begin{tabular}{|c|c|c|c|}
\hline 2.10 .1 .5 & $\begin{array}{c}\text { Kvalita } \\
0 \\
1 \\
3 \\
4 \\
5\end{array}$ & $\begin{array}{l}\text { jako kritérií nebo markerů: } \\
\text { Žádná informace neposkytnuta. } \\
\text { Poskytnuta neadekvátní informace. } \\
\text { Adekvátní kvalita. } \\
\text { Dobrá kvalita. } \\
\text { Vynikajíć kvalita s širokým rozsahem relevantních markerů pro } \\
\text { konvergentní a divergentní validizaci. }\end{array}$ & 0 \\
\hline 2.10 .1 .6 & $\begin{array}{r}\text { Analýz } \\
{[\mathrm{N}} \\
0-\end{array}$ & $\begin{array}{l}\text { ciálního fungování položek (DIF): } \\
\text { Nepoužitelné } \\
\text { hodnocení kvality DIF analýzy }\end{array}$ & 0 \\
\hline 2.10 .2 & $\begin{array}{l}\text { Validi } \\
\text { (Tento ce } \\
2.11 .1-2\end{array}$ & $\begin{array}{l}\text { jjící se ke kritériu - celková adekvátnost } \\
\text { se získá na základě posouzení hodnot ratingů daných v položkách } \\
\text { ruuměrujte pouze čísla, abyste získali celkový rating.) }\end{array}$ & 1 \\
\hline 2.10.2.1 & $\begin{array}{r}\text { Popis } 1 \\
\square \\
\square \\
\square\end{array}$ & $\begin{array}{l}\text { kritérií a charakteristik populací: (zatrhněte tolik, kolik je po } \\
\text { ná } \\
\text { tivní } \\
\text { tivní }\end{array}$ & \\
\hline 2.10 .2 .2 & $\begin{array}{c}\text { Velikc } \\
0 \\
1 \\
3 \\
4 \\
5\end{array}$ & $\begin{array}{l}\text { rů: } \\
\text { Žádná informace neposkytnuta. } \\
\text { Jedna neadekvátní studie (nap̌r. velikost výběru menší než 100). } \\
\text { Jedna adekvátní studie (např. velikost výběru 100-200). } \\
\text { Jedna velká nebo vice než jedna adekvátně rozsáhlá studie. } \\
\text { Dobrá série adekvátních až rozsáhlých studií. }\end{array}$ & 1,5 \\
\hline 2.10.2.3 & $\begin{array}{r}\text { Proced } \\
\text { (vyberte } \\
\square \\
\square \\
\square \\
\square\end{array}$ & $\begin{array}{l}\text { iru souboru: } \\
\text { informace neposkytnuta } \\
\text { nebo reprezentativní } \\
\text { lá } \\
\text { ná }\end{array}$ & \\
\hline 2.10.2.4 & \begin{tabular}{|c} 
Mediár \\
0 \\
1 \\
3 \\
4 \\
5
\end{tabular} & $\begin{array}{l}\text { h korelací mezi testem a kritérii: } \\
\text { Žádná informace neposkytnuta. } \\
\text { Neadekvátní (např. } \mathrm{r}<0.2 \text { ). } \\
\text { Adekvátní (např. } 0.2<\mathrm{r}<0.35 \text { ). } \\
\text { Dobrý (např. } 0.35<\mathrm{r}<0.50 \text { ). } \\
\text { Vynikající (např. } \mathrm{r}>0.50 \text { ) }\end{array}$ & $\begin{array}{l}4 \text { (korelace } \\
\text { s kritérii } \\
\text { neuvedeny, } \\
\text { jedná se o } \\
\text { odhad autorů } \\
\text { recenze na } \\
\text { základě } \\
\text { uvedených } \\
\text { dat) }\end{array}$ \\
\hline \multicolumn{4}{|c|}{ 2.10.3 Komentáře recenzenta týkající se validity: } \\
\hline \multicolumn{4}{|c|}{$\begin{array}{l}\text { Validita nástroje BRIEF je problematická z několika důvodů. V první řadě je diskutabilní samotná } \\
\text { faktorová struktura, kterou autoři BRIEF navrhují. Autoři uvádí, že v rámci pilotní studie provedli } \\
\text { explorační faktorovou analýzu (EFA), která byla provedena na } 129 \text { položkách od } 120 \text { respondentů-rodiču a } \\
127 \text { položkách od } 120 \text { respondentů-učitelů. Její výstupy ovšem nejsou reportovány. Současně se } \\
\text { domníváme, že takto nízký vzorek je při tak vysokém počtu položek nedostatečný. V EFA byla navíc } \\
\text { použita ortogonální rotace, která nám také nepřipadá vzhledem k teorii, ze které autoři vychází, ani } \\
\text { následné operaci se skóry vhodná. Navíc v navazující studii na rozsáhlejším vzorku už autoři BRIEF } \\
\text { předpokládanou faktorovou strukturu neověřovali, pouze zkoumali mezipoložkovou korelaci a korelaci } \\
\text { položky s celkovým skóre pro danou škálu. Konfirmační faktorová analýza by nám v tomto kontextu přišla } \\
\text { vhodnější. Dohledali jsme ale několik studií, v nichž byla provedena konfirmační faktorová analýza } \\
\text { (CFA) se součtovými skóry klinických škál jako manifestními proměnnými (Egeland \& Fallmyr, 2010; } \\
\text { Fournet et al., 2015, Gioia et al., } 2002 \text {; Lyons Usher et al., 2016; Peters et al., 2012). Jejich výsledky } \\
\text { poukazují na to, že ani jednoduché jednofaktorové řešení (faktor odpovídající GEC), ani jednoduché } \\
\text { řešení se dvěma korelovanými faktory odpovídajícími indexům BRI a MI (sycenými stejnými škálami, } \\
\text { z jejichž součtu jsou dle manuálu indexy vytvořeny) nepopisuje data dobře. Validita jak indexů BRI a } \\
\text { MI, tak kompozitního skóru GEC, je proto značně problematická (možná i proto je v manuálu } \\
\text { uvedeno, že by měla být dána přednost interpretaci jednotlivých škál a testového profilu namísto } \\
\text { indexů, nicméně bychom uvítali zdůvodnění proč). V jedné dohledané studii (Huizinga \& Smidts, } \\
\text { 2011) byla provedena CFA se samostatnými položkami jako indikátory. Zde bylo podpořeno }\end{array}$} \\
\hline
\end{tabular}


osmifaktorové řešení odpovídající osmi klinickým škálám (s povolením tří mezipoložkových reziduálních korelací). Některé faktory nicméně vzájemně velmi silně korelovaly ( $\mathrm{v}$ šesti př́ípadech $\mathrm{r}$ $>0,75$, z toho ve dvou př́padech $r>0,85$; i v manuálu spolu některé škály velmi silně korelují - byt' na úrovni součtových skórů) a zároveň nebylo testováno alternativní faktorové řešení. Interpretace skórů z klinických škál je tak vzhledem k velmi omezené empirické podpoře také problematická.

Konstruktová validita byla dle autorů posuzována pomocí korelací s dalšími dotazníky založenými na principu hodnocení chování dítěte rodičem a/nebo učitelem. Škály BRIEF korelují se škálami použitých měřících nástrojů většinou dle očekávání. Přesto ale manuál obsahuje několik logických inkonzistencí nebo nedostatečných informací. Za prvé se vůbec nevyjadřuje ke vztahu škály

Organizace pomůcek. Za druhé selektivně reportuje výsledky korelací - např. u Inhibice se vyjadřuje ke vztahu se škálou Poruch pozornosti Dotazníku Hodnocení Dětského Chování (CBCL), ale nikoliv u podobných škál obsažených v Hodnocení Dětského Chování Učitelem (TRF) a v Hodnocení Dětského Chování (BASC). V neposlední řadě nechává logické inkonzistence bez komentáře - např. Index regulace chování (BRI) z verze pro rodiče měl téměř nulový vztah se Škálou poruch chování v BASC. V případě verze pro učitele manuál uvádí pouze rozpětí korelací jednotlivých škál se Škálou poruch chování BASC. Tyto korelace byly relativně silné. Jako nedostatek vidíme i to, že se posouzení konstruktové validity nástroje opírá pouze o jiné dotazníkové metody pro rodiče/učitele. Autoři nevyužili žádných výkonových nebo observačních metod pro měření exekutivních funkcí dítěte. Studie, která porovnávala skóry pracovní paměti z BRIEF se skóry pracovní paměti získané pomocí WJ-III Cog, zjistila velmi slabý vztah (Milke, 2014). Současně Vriezen a Pigott (2002) nenašli u dětí s traumatickým poraněním mozku žádný vztah mezi indexy BRIEF z verze pro rodiče a výkonovými testy měřícími exekutivní funkce, ačkoliv autoři zdůrazňují možnou nedostatečnou senzitivitu, která $\mathrm{v}$ době vzniku studie nebyla pro zvolené výkonové metody v dětské populaci dostatečně prozkoumána.

V neposlední řadě se autoři zabývali porovnáním průměrných skórů mezi klinickými a kontrolními skupinami pro různé vývojové, neurologické, psychiatrické a jiné poruchy. Klinická a kontrolní skupina byla párovaná vždy minimálně na základě věku, pohlaví a SES, v některých případech i na základě etnika. Bohužel informace ohledně kriteriální validity neposkytují dostatečný obrázek o vhodnosti metody BRIEF. V první řadě, manuál se spíše než na velikost účinku rozdílů mezi klinickými a kontrolními skupinami soustředí na statistickou signifikanci, od které odvíjí argumentaci. Navíc hodnotu velikosti účinku přímo neudává, nicméně ji lze dopočítat z uvedených průměrů a směrodatných odchylek. Přesto ale explicitní neuvedení velikosti účinku značně omezuje uživatelskou př́větivost manuálu. Dopočítané korelace mezi skóry na jednotlivých škálách, resp. indexech, se pohybují v rozmezí $0 \leq r<0,91$; v průměru jsou korelace středně silné (medián odpovídá 0,44 ). V řadě druhé - manuál neuvádí, jaké vztahy mezi skóry na škálách (resp. indexech) BRIEF u té které poruchy očekává a pouze reportuje signifikantní rozdíly bez vztažení k teorii. Například informace uvedené u včasně léčené fenylketonurie (PKU) mohou vyznívat tak, že pacienti s PKU mají problém pouze s úzkým výsekem exekutivních funkcí. Nicméně studie, které pracovaly s výkonovými testy uvádí snížený výkon v několika oblastech exekutivních funkcí, včetně inhibice, pracovní paměti, přesunu pozornosti nebo i v otázce řešení úkolů (ačkoliv údaje pro poslední dvě složky se výsledky např́íc studiemi liší; Christ et al., 2010). Rozdíly ve většině škál a indexů mezi pacienty s PKU a kontrolní skupinou jsou ale u BRIEF verze pro rodiče nejen statisticky nevýznamné, ale také poměrně slabé $(0,01$ $<r<0,35$; medián korelací 0,08). Poměrně slabý vztah skórů u verze pro rodiče je i u pacientů $\mathrm{s}$ vážným traumatickým poraněním mozku v porovnání s hospitalizovanými ortopedickými pacienty $(0,03<r<0,28$; medián korelací 0,23), u mentální retardace $(0 \leq r<0,52$; medián korelací 0,22$)$ a u dětí s nízkou porodní váhou v porovnání s dětmi narozenými v termínu (pro extrémně nízkou porodní váhu: $0,08<r<0,35$; medián korelací 0,27 ; pro velmi nízkou porodní váhu: $0,01<r<0,13$; medián korelací 0,1 ). Naopak středně silné až silné jsou vztahy mezi skóry na škálách i indexech (ve verzi pro rodiče) a diagnostikovanou poruchou pro ADHD (pro ADHD-I: 0,11 $<r<0,66$; medián korelací 0,47; pro ADHD-C 0: $44<r<0,68$; medián korelací 0,52), vysokofunkční autismus $(0,6<r<0,91$; medián korelací 0,85$)$ a pervazivní vývojové poruchy $(0,31<r<0,66$; medián korelací 0,5$)$. Obdobný trend lze pozorovat i u verze pro učitele (ADHD-I: 0,32 $<r<0,63$; medián korelací 0,48; ADHD-C: 0,42 $<r<0,65$; medián korelací 0,58, vysokofunkční autismus: $0,42<r<0,7$; medián korelací 0,56; pervazivní vývojové poruchy: $0,36<r<0,62$; medián korelací 0,56 ). Nakonec jako vážný nedostatek u kriteriální 
validity vidíme i nerovnoměrné ověření verze pro učitele a pro rodiče $v$ různých skupinách (verze pro rodiče ověřena ve všech skupinách, verze pro učitele pouze u ADHD, vysokofunkčního autismu a pervazivních vývojových poruch).

Co se týče validizačních škál (Škála inkonzistence a Škála negativity) autoři neuvádějí žádné důkazy jejich validity. V př́padě Škály inkonzistence dle našeho názoru rozdíly v odpovědích na dvojice podobně formulovaných položek nemusí nutně indikovat inkonzistenci v odpovídání respondenta. Některé dvojice položek se svým zněním liší natolik, že mohou vyjadřovat jinou fasetu měřeného konstruktu (např. Vyrušuje ostatní. a Mluví, když nemá.) nebo mohou být různě obtížné (např. Mívá záchvaty vztahu a je výbušný/á. a Vzteká se kvưli maličkostem.) a nekonzistence v odpovědích na takové položky tak může být spíše důsledkem těchto faktorů. $\mathrm{V}$ př́ípadě položek Škály negativity byla ve standardizační studii poměrně málo volena odpověd' Často. Vysoká četnost těchto odpovědí, tak může dle autorů poukazovat na výjimečně negativní percepci dítěte ze strany posuzujícího. Autoři ale zároveň uvádějí, že vysoký skór na Škále negativity může reflektovat i skutečně silné narušení exekutivních funkcí dítěte. Možnost nevalidních odpovědí vyplývající z obou škál by proto z našeho pohledu měla být interpretována obezřetně a s přihlédnutím $\mathrm{k}$ dalším dostupným informacím o dítěti. Autoři manuálu doporučují se $\mathrm{v}$ př́ípadě podezření na nevalidní odpovědi doptat respondenta na okolnosti nekonzistentního/negativního odpovídání.

\section{Reliabilita}

\begin{tabular}{|c|c|c|c|}
\hline 2.11 & $\begin{array}{l}\text { Celková adekvá } \\
\text { (Tento celkový rating se } \\
\text { Neprüměrujte pouze c }\end{array}$ & $\begin{array}{l}\text { étnost: } \\
\text { czíská na základě posouzení hodnot ratingů daných v položkách 2.11.1-2.10.2.4. }\end{array}$ & 4 \\
\hline 2.11.1. & \multicolumn{3}{|c|}{$\begin{array}{c}\text { Poskytnutá data týkající se reliability: (vyberte jednu možnost) } \\
\square \quad \text { Uveden pouze jeden koeficient reliability } \\
\square \quad \text { Uveden pouze jeden odhad standardní chyby měření } \\
\square \quad \text { Koeficienty reliability pro několik různých skupin } \\
\square \quad \text { Standardní chyba měření uvedená pro několik různých skupin }\end{array}$} \\
\hline 2.11 .1 & \multicolumn{3}{|c|}{ Vnitřní konzistence: } \\
\hline 2.11 .1 .1 & \multicolumn{2}{|c|}{\begin{tabular}{|cl} 
Velikost výběru: \\
0 & Neposkytnuta žádná informace. \\
1 & Jedna neadekvátní studie (např. rozsah výběru menší než 100). \\
3 & Jedna adekvátní studie (např. rozsah výběru 100-200). \\
4 & Jedna rozsáhlá nebo vice než jedna adekvátně rozsáhlá studie. \\
5 & Dobrá série adekvátních až rozsáhlých studií. \\
{$[\mathrm{N} / \mathrm{A}]$} & Nepoužitelné. \\
\end{tabular}} & 4 \\
\hline 2.11 .1 .2 & $\begin{array}{l}\text { Medián koeficien } \\
0 \\
1 \\
3 \\
4 \\
5 \\
{[\mathrm{~N} / \mathrm{A}]}\end{array}$ & $\begin{array}{l}\text { Atů: } \\
\text { Neposkytnuta žádná informace. } \\
\text { Neadekvátní (např. } r<0.7 \text { ) } \\
\text { Adekvátní (např. } r=0.7 \text { až } 0.79 \text { ) } \\
\text { Dobrý (např. } r=0.8 \text { až } 0.89 \text { ) } \\
\text { Vynikající (např. r }>0.9 \text { ) } \\
\text { Nepoužitelné. }\end{array}$ & 4 \\
\hline 2.11 .2 & \multicolumn{3}{|c|}{ Testová-retestová stabilita: } \\
\hline 2.11.2.1 & \multicolumn{2}{|c|}{\begin{tabular}{|cl} 
Rozsah výběru: & \\
0 & Neposkytnuta žádná informace. \\
1 & Jedna neadekvátní studie (např. rozsah výběru menší než 100). \\
3 & Jedna adekvátní studie (např. rozsah výběru 100-200). \\
4 & Jedna rozsáhlá nebo vice než jedna adekvátně rozsáhlá studie. \\
5 & Dobrá série adekvátních až rozsáhlých studií. \\
\end{tabular}} & 1 \\
\hline 2.11 .2 .2 & $\begin{array}{c}\text { Medián koeficien } \\
0 \\
1 \\
3 \\
4 \\
5 \\
\end{array}$ & $\begin{array}{l}\text { atů: } \\
\text { Neposkytnuta žádná informace. } \\
\text { Neadekvátní (např. } r<0.6 \text { ) } \\
\text { Adekvátní (např. } r=0.6 \text { až } 0.69 \text { ) } \\
\text { Dobrý (např. r }=0.7 \text { až } 0.79 \text { ) } \\
\text { Vynikající (např. } r>0.8 \text { ) }\end{array}$ & 5 \\
\hline 2.11 .3 & \multicolumn{3}{|c|}{ Reliabilita jako ekvivalence: } \\
\hline
\end{tabular}




\begin{tabular}{|c|c|c|c|}
\hline 2.11.3.1 & $\begin{array}{l}\text { Rozsah výběru: } \\
0 \\
1 \\
3 \\
4 \\
5 \\
{[\mathrm{~N} / \mathrm{A}]} \\
\end{array}$ & $\begin{array}{l}\text { Neposkytnuta žádná informace. } \\
\text { Jedna neadekvátní studie (např. rozsah výběru menší než 100). } \\
\text { Jedna adekvátní studie (např. rozsah výběru 100-200). } \\
\text { Jedna rozsáhlá nebo vice než jedna adekvátně rozsáhlá studie. } \\
\text { Dobrá série adekvátních až rozsáhlých studií. } \\
\text { Nepoužitelné. }\end{array}$ & {$[\mathrm{n} / \mathrm{a}]$} \\
\hline 2.11 .3 .2 & $\begin{array}{c}\text { Medián koeficie } \\
0 \\
1 \\
3 \\
4 \\
5 \\
{[\mathrm{~N} / \mathrm{A}]}\end{array}$ & $\begin{array}{l}\text { ntů: } \\
\text { Neposkytnuta žádná informace. } \\
\text { Neadekvátní (např. } r<0.6 \text { ) } \\
\text { Adekvátní (např. r }=0.6 \text { až 0.69) } \\
\text { Dobrý (napřr. r }=0.7 \text { až } 0.79 \text { ) } \\
\text { Vynikající (např. r>0.8) } \\
\text { Nepoužitelné }\end{array}$ & {$[\mathrm{n} / \mathrm{a}]$} \\
\hline
\end{tabular}

\subsubsection{Komentáře recenzentů k reliabilitě:}

- Komentujte intervaly spolehlivosti pro koeficienty reliability

- Uved'te Spearmanovy-Brownovy ekvivalenty

Autoři jak americké, tak české standardizační studie uvádí pouze rozpětí odhadů vnitřní konzistence (koeficient alfa) např́íč subškálami a kompozitními skóry. . Rozpětí odhadů prezentované v manuálu jsou navíc spočítané pro celý soubor napříč věkem, a jsou tedy pravděpodobně nadhodnocené. Tyto odhady vnitřní konzistence se pohybují $\mathrm{v}$ rozmezí $0,80-0,98 \mathrm{v}$ př́padě americké standardizace, 0,81-0,92 v případě české standardizace. Odhady vnitřní konzistence pro jednotlivé subškály a kompozitní skóry lze nicméně zpětně dopočítat $\mathrm{z}$ hodnot pro výpočet $90 \%$ intervalů spolehlivosti, které jsou uvedeny $\mathrm{v}$ tabulkách norem, a to i pro jednotlivé věkové skupiny zvlášt'. Z nich lze dovodit, že vnitřní konzistence některých subškál v určitých věkových skupinách je nižší než 0,8 (např. subškála Iniciativa, chlapci 8-10 let, verze pro rodiče), v některých prŕpadech se dokonce pohybuje okolo hodnoty 0,7 (např. subškála Organizace pomůcek, chlapci 14-18 let, verze pro učitele). Informace uvedené v manuálu tak nejsou plně v souladu s informacemi v tabulkách norem. Vnitřní konzistence indexů BRI a MI a celkového skóru GEC je ale pro všechny věkové skupiny a obě verze dotazníku velmi dobrá (nejnižší hodnoty se pohybují okolo 0,91 ).

Test-retest reliabilita byla posuzována ve dvou podskupinách (normativní a klinická) u verze pro rodiče (časový rozestup 2-3 týdnů) a jedné podskupině (z manuálu není jasné, zda šlo o normativní nebo klinickou) u verze pro učitele (časový rozestup 3,5 týdne). Medián test-retest korelací pro klinické škály přesahuje ve všech př́padech hodnotu 0,8 , to samé platí i pro indexy BRI, MI a kompozitní skór GEC. Velikosti test retest-korelací se zdají být velmi dobré, mohly být ale zkresleny (potažmo nadhodnoceny) jednak poměrně krátkými časovými rozestupy mezi jednotlivými administracemi, jednak relativně malými velikostmi vzorku $(N=40-54)$, které mohly vést $\mathrm{k}$ nepřesnému odhadu. $\mathrm{V}$ př́padě české standardizace jsou uvedeny pouze průměrné rozdíly skórů bez odhadů test-retest reliability. U těchto rozdílů navíc není jasné, zda jde o rozdíl hrubých skórů nebo T-skórů.

V případě alternativních forem BRIEF (verze pro rodiče, verze pro učitele) nelze hovořit o paralelních testech ani míre paralelnosti v pravém slova smyslu. Verze jednak obsahují část položek rozdílných, jednak je počet položek u většiny škál odlišný v jedné a druhé verzi, jednak je každá verze hodnocena odlišným hodnotitelem (rodič/učitel). Autoři americké standardizace uvádějí korelace jednotlivých škál mezi oběma verzemi spočítané na vzorku $N=296$. V př́padě klinických škál jsou korelace mezi verzí pro rodiče a pro učitele u čtyř z nich nižší než 0,2 , u dvou se pohybují okolo 0,3 , a pouze u dvou jsou vyšší než 0,4 . Korelace BRI, MI a GEC přesahují ve všech třech případech mírně hodnotu 0,3. Vzájemné korelace škál mezi verzí pro rodiče a pro učitele tak nelze považovat za adekvátní. Jejich interpretace je ale vzhledem $\mathrm{k}$ odlišnostem obou verzí problematická a nelze ji chápat ani jako korelaci paralelních testů, ani jako shodu posuzovatelů v pravém slova smyslu. Jde spíše o ukazatel konvergentní validity - i z tohoto pohledu jsou vzájemné korelace poměrně slabé a poukazují na problematičnost možnosti srovnatelné interpretace skórů v obou verzích. 


\section{Část 8:}

\section{Kvalita počítačově generovaných zpráv:}

Položky mají být posuzovány n/a nebo 0 až 5 (poloviční rating je přijatelný)

Rating

\begin{tabular}{|c|c|c|}
\hline 2.12 & $\begin{array}{l}\text { Celková adekvátnost počítačově generovaných zpráv: } \\
\text { (Tento celkový rating se získá na základě posouzení hodnot ratingů daných pro položky 2.12.1-2.12.7. } \\
\text { Neprủměrujte pouze hodnoty, abyste získali celkový rating.) }\end{array}$ & 3 \\
\hline 2.12 .1 & 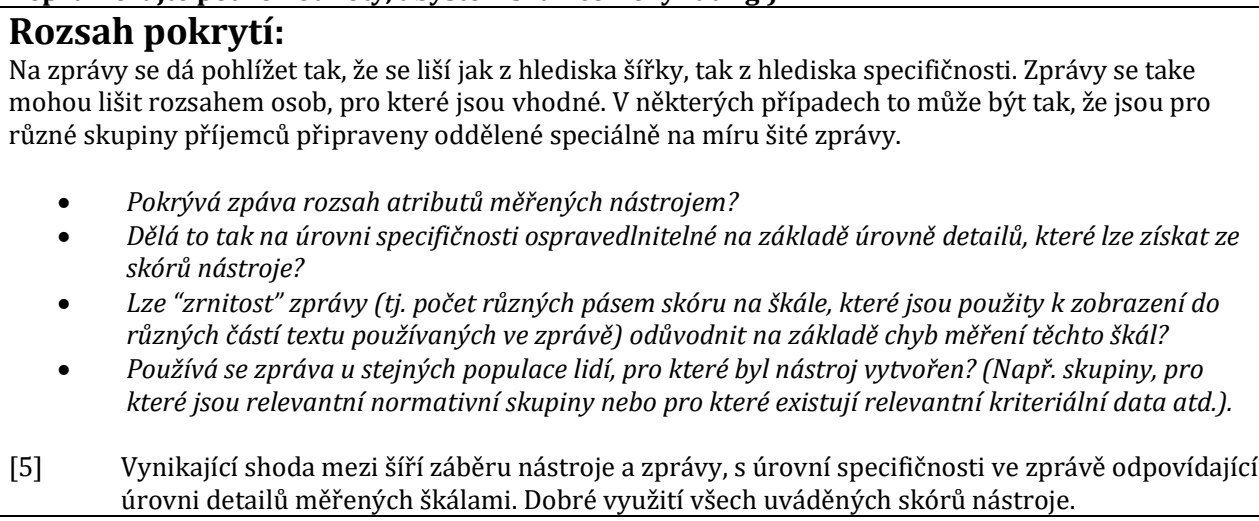 & 3 \\
\hline 2.12 .2 & $\begin{array}{l}\text { Reliabilita } \\
\text { - Jak konsistentní jsou zprávy ve své interpretaci podobných sad skórů? } \\
\text { - Pokud je obsah zprávy variabilní (např. náhodným výběrem z ekvivalentních částí textu), je to } \\
\text { prováděno uspokojivě? } \\
\text { - Je interpretace skórů a rozdílů mezi skóry ospravedlnitelná z hlediska chyb měření škál? } \\
\text { [5] } \quad \begin{array}{l}\text { Vynikající konsistence při interpretaci a přiměřená varování poskytnutá u tvrzení, interpretací } \\
\text { a doporučení týkajících se souvisejících chyb měrení. }\end{array} \\
\end{array}$ & 1 \\
\hline 2.12 .3 & $\begin{array}{l}\text { Relevance neboli validita } \\
\text { Spojení mezi nástrojem a obsahem zprávy může být bud' vysvětlena v rámci zprávy nebo dokumentováno } \\
\text { odděleně. Kde jsou zprávy založené na klinickém úsudku, by měl být dokumentován process, kterým } \\
\text { expert(i) vytvářel(i) obsah a pravidla dávající do vztahu skóry a obsah. } \\
\text { - Jak silný je vztah mezi obsahem zprávy a skóry nástroje? Do jaké míry jde zpráva za nebo se } \\
\quad \text { rozchází s informacemi poskytovanými skóry nástroje? } \\
\text { - Je obsah zprávy v jasném vztahu k charakteristikám měřeným nástrojem? } \\
\quad \begin{array}{l}\text { Poskytuje rozumné závěry o kritériích, ke kterým můžeme očekávat, že budou takové } \\
\text { charakteristiky ve vztahu? }\end{array} \\
\text { - Jaké empirické důkazy jsou poskytnuty, které ukazují, že tyto vztahy skutečně existují? } \\
\text { Je relevantní uvažovat jak o konstruktové validitě zprávy (tj. míře, do jaké poskytuje interpretaci, která je } \\
\text { ve shodě s př́slušnými konstrukty) a kriteriální validitě (tj. kde jsou formulovány výroky, které lze davit } \\
\text { zpětně do vztahu s empirickými daty). } \\
\text { [5] } \quad \text { Vynikají vztah mezi škálami a obsahem zprávy spolu s jasnými odůvodněními. } \\
\text { [5] }\end{array}$ & 5 \\
\hline 2.12 .4 & $\begin{array}{l}\text { Spravedlnost neboli nezávislost na systematickém zkreslení } \\
\text { - Mohl by obsah zprávy a použitý jazyk vytvářet dojem nepatřičnosti pro určité skupiny? } \\
\text { - Vyjasňuje zpráva jakékoli oblasti možného zkreslení ve výsledcích nástroje? } \\
\quad \text { zajišténí jejich ekvivalence? } \\
\text { [5] Vynikající, jasná varování a vysvětlení možného zkreslení, dostupné ve všech relevantních } \\
\text { uživatelských jazycích }\end{array}$ & 3 \\
\hline 2.12 .5 & $\begin{array}{l}\text { Přijatelnost } \\
\text { Ta bude velmi záviset na komplexnosti jazyka použitého ve zprávě, složitosti popisovaných konstruktů a } \\
\text { účelu, pro jaký je určena. } \\
\text { • Dá se očekávat, že forma a obsah zprávy budou přijatelné zamýšleným př́ijemcúm? } \\
\text { - Je zpráva napsána jazykem, který je přiměřený pravděpodobným úrovním počtárské zběhlosti a } \\
\text { gramotnosti předpokládaného čtenáre? } \\
\text { [5] Velmi vysoká přijatelnost, dobře navržená a dobře se hodící předpokládaným př́ijemcům }\end{array}$ & 1 \\
\hline
\end{tabular}




\begin{tabular}{|c|c|c|}
\hline 2.12 .6 & $\begin{array}{l}\text { Praktičnost } \\
\text { Otázky praktičnosti take ovlivňují přijatelnost. Hlavní praktická výhoda počítačově generovaných zpráv je } \\
\text { ta, že šetří čas osoby, která by jinak musela zprávu vytvořit. Když tato osoba není koncový uživatel, } \\
\text { argumenty týkajíí se praktičnosti mohou být obtížněji formulovatelné. } \\
\text { • Kolik času šetří každá zpráva uživateli? } \\
\quad \text { Kolik času zabere čtení a používání každé zprávy? } \\
\text { [5] Vynikající z hlediska efektivity a hodnoty. }\end{array}$ & 3 \\
\hline 2.12 .7 & $\begin{array}{l}\text { Délka } \\
\text { Toto je aspekt praktičnosti a měl by se projevit v tomto ratingu. Konkrétněji poskytuje index } \\
\text { poměru kvantity výstupu ku vstupu. Počet škál, na kterých je založen obsah zprávy, je } \\
\text { považován za vstup, a počet stránek zprávy (mimo titulních stránek, poznámek týkajících se } \\
\text { copyrightu atd.) jsou považovány za výstup. } \\
\text { Pro výpočet tohoto indexu sečtěte počet škál včetně odvozených a kompozitních škál (napřs pro } \\
\text { osobnostní míry, faktorové škály vyšśího řádu, škály pro typy týmů, styly vedení atd. Mohou } \\
\text { být odvozeny ze základních škál). } \\
\qquad \begin{array}{l}1 . \quad \text { Vydělte celkový počet stránek počtem škál. } \\
2 \text {. Vynásobte tento zlomek } 10 \text { a zaokrouhlete výsledek na nejbližší celé číslo. } \\
\text { Hodnoty vyšśí než } 10 \text { obecně pravděpodobně indikují zprávy, které jsou nadměrně dlouhé a } \\
\text { přehnaně interpretující }\end{array} \\
\text { Např.: Vývojová zpráva }-8 / 7 \text { x } 10=11.42 \text {. }\end{array}$ & 11 \\
\hline
\end{tabular}

Počítačově generované zprávy vidíme spíš jako alternativu pro ušetření času nutného pro skórování, výpočty skórů z jednotlivých škál, dílčích indexů i celkového skóre. Přesto bychom ale nedoporučovali se opírat o samotné skóry a závěry zprávy. Zaprvé, na rozdíl od papírové verze, zpráva zcela pozbývá intervaly spolehlivosti. Interpretace, zdali je T-skór daného dítěte v dané škále normální/(sub)klinický, se tak opírá pouze o bodový odhad, což dle našeho názoru není př́klad dobré diagnostické praxe. Co se týče další interpretace skóru (kromě roviny normální/(sub)klinický), text neobsahuje další části, které by se lišily pro respondenty s různými skóry. Jedinou výjimkou je celkový skór GEC, u kterého se v př́ípadě rozdílu mezi MI a BRI vyššího než 13 T-skórů objeví zpráva, že tento skór nemůže být interpretován (tato informace ovšem chybí v manuálu). Pod každou škálou text dále vždy krátce shrnuje, k čemu se škála vztahuje nebo kde může hrát roli ve výkonu/chování dítěte. Další interpretace je potom přenechána na adresátovi zprávy.

Zpráva dále poskytuje informace o možných zkresleních. Ačkoliv se metoda, a tedy ani zpráva nevěnují otázce férovosti (viz Část 7: Validita), zpráva se zabývá otázkou možných zkreslení odpovědi. Stejně jako ve verzi papír-tužka poskytuje skóry validizačních škál - škály inkonzistence a škály negativity i adekvátní interpretací těchto škál s doporučeným postupem. Přesto např. u škály negativity chybí dle našeho názoru důležitá informace z manuálu, že vyšší skór může indikovat i skutečně vysokou míru problému v exekutivních funkcí. Dále je ve zprávě uvedeno rozložení jednotlivých odpovědí, zdali (a také kolikrát a na jak dlouho) respondent přerušil testování a vystoupil z aplikace HTS 5 . V neposlední řadě je pro každou položku poskytnutý čas, kterou nad ní respondent strávil.

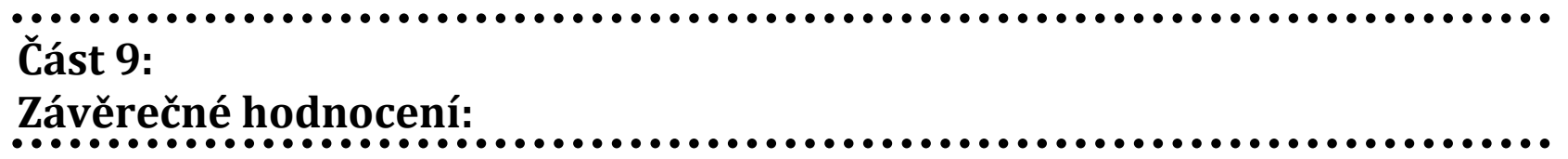

3.0 Hodnotící zpráva testu:

Tato část by měla obsahovat stručné, jasně obhájené posouzení nástroje/produktu. Mělo by popisovat jeho pro a proti a poskytnout určitá obecná doporučení týkající se toho, jak a kdy by se měl používat - spolu s varováními (kde jsou potřebná) týkajícími se případů, kde by se používat neměl. 
BRIEF představuje relativně snadno administrovatelný nástroj pro posouzení dílčích aspektů exekutivních funkcí u dětí a dospívajících ve věku 5-18 let. Metoda má potenciál být užitečným screeningovým nástrojem $\mathrm{v}$ neuropsychologické a poradensko-psychologické diagnostice díky relativní srozumitelnosti položek a snadné proceduře administrace a vyhodnocování. Informace poskytnuté dodavatelem $\mathrm{k}$ administraci a vyhodnocování BRIEF jsou dostatečné. Standardizace původní i české verze BRIEF nicméně trpí několika zásadními nedostatky, na základě kterých lze doporučit využití metody v diagnostické praxi pouze ve velmi omezených aplikačních oblastech (viz Závěr).

V manuálu jsou nedostatečně uvedeny důkazy o faktorové validitě BRIEF. Není proto jasné, zda skóry jednotlivých škál skutečně vyjadřují zamýšlené konstrukty. Autoři manuálu v tomto ohledu pouze chybně argumentují vysokými hodnotami koeficientů alfa (viz např. Marko, 2016), které podle nich poukazují na to, že položky škály měří tentýž konstrukt. Interpretace skórů, tak jak je doporučována $\mathrm{v}$ manuálu (tj. jednak na úrovni osmi klinických škál, jednak na úrovni indexů BRI a MI, jednak na úrovni celkového skóru GEC), je kvůli absenci důkazů o faktorové struktuře problematická. Závěry několika studií (viz sekci Validita) navíc dokládají, že empirická struktura BRIEF se spíše liší od dimenzí navrhovaných v manuálu. To značně limituje možnosti interpretace jednotlivých skórů.

Za naprosto zásadní nedostatek české verze BRIEF pokládáme absenci lokálních norem pro Českou republiku. Americké normy nepovažujeme vzhledem k jejich neporovnatelnosti co do demografických charakteristik a zastaralosti za vhodné pro využívání v českém prostředí. Velikosti rozdílů mezi českým a americkým vzorkem $v$ průměrech subškál navíc naznačují, že mohou některé subškály v českém prostředí fungovat jinak než v americkém. Využívání amerických norem se proto nezdá být adekvátní. Americké normy jsou navíc v případě verze BRIEF pro učitele založeny u většiny věkových kategorií na velmi malých vzorcích.

Pro férové využívání testu by navíc bylo vhodné získat informace o diferenciálním fungování položek a invarianci měření. Invariance byla doposud zkoumána pouze pro jednotlivé věkové kategorie na vzorku francouzském (Fournet et al., 2015; plná invariance podpořena pouze na metrické úrovni) a nizozemském vzorku (Huizinga \& Smidts, 2011; podpořena invariance na skalární úrovni). Za nezbytné ale považujeme získání důkazů také o invarianci pro pohlaví, různé úrovně SES rodiny nebo etnické menšiny (v ČR např. romské a vietnamské populace).

V americkém prostředí je k dispozici již druhá revize BRIEF-2 (Gioia et al., 2015), která se od první verze liší hlavně pozměněným počtem a interpretací subškál i dílčích indexů. Také je metoda kromě verze dotazníku pro rodiče a učitele rozšířena o sebeposuzovací dotazník pro děti a adolescenty ve věku od 11 do 18 let. Oproti BRIEF do BRIEF-2 nebyly přidány žádné položky, jednotlivé verze ale mají být vzájemně více paralelní. Současně druhá revize oproti první obsahuje navíc 12položkové screeningové formuláře pro učitele, rodiče i pro samotné děti/adolescenty.

\subsection{Závěry:}

Vzhledem k nedostatečným důkazům o faktorové struktuře BRIEF, a tudíž i o možnostech interpretace jednotlivých skórů, a kvůli chybějícím českým normám doporučujeme využívat BRIEF v běžné diagnostické praxi pouze ve velmi omezených aplikačních oblastech. Dle našeho názoru může být metoda BRIEF užitečná pouze jako nástroj pro prvotní screening potenciálního narušení exekutivních funkcí. Výsledky by ale měl být interpretovány nanejvýš obezřetně a informace získané administrací BRIEF by měly být vždy dávány do souvislosti s dalšími zdroji informací získaných během vyšetření. Rozhodně ale nelze BRIEF považovat za ukazatel kvality exekutivních funkcí v jednotlivých doménách fungování. Pro účel jednoznačnější interpretace výsledků BRIEF je nezbytné provést důkladnější českou standardizaci zahrnující sestavení norem reflektujících demografické charakteristiky České republiky. Je také nutné získat 
důkazy o validitě BRIEF a invarianci metody pro různé skupiny. Vzhledem k již publikované druhé verzi metody (BRIEF-2; Gioia et al., 2015) je ale otázkou, zda by nebylo vhodnější zohlednit uvedené prvky spíše v př́ípadné standardizaci této nové verze.

\begin{tabular}{|c|c|}
\hline \multicolumn{2}{|c|}{ 4.0 Doporučení (vyberte jedno) } \\
\hline \multicolumn{2}{|c|}{$\begin{array}{l}\text { Všechny následující charakteristiky } \\
\text { uvedené níže by měly mít ratingy } \\
\text { [n/a], [2], [4], [5], pokud by měl být } \\
\text { nástroj „doporučen“ pro obecné } \\
\text { použití (hodnocení } 5 \text { nebo 6): }\end{array}$} \\
\hline [2.9] & iny \\
\hline [2.10.1] & ova v \\
\hline [2.10.2] & \\
\hline [2.11] & Reli \\
\hline $\begin{array}{l}\text { [2.12] } \\
\text { zprávy }\end{array}$ & ge \\
\hline $\begin{array}{l}\text { Pokud } \mathrm{n} \\
\text { ratingů } \\
\text { měl být } \\
1,2,3 \mathrm{n} \\
\text { doporu }\end{array}$ & $\begin{array}{l}\text { erýkoli z výše uvedených } \\
\text { lotu [] nebo [1], nástroj by } \\
\text { fikován pod doporučením } \\
\text { 4, nebo klasifikován pod } \\
\text { n } 7 \text { "jiné” s adekvátním }\end{array}$ \\
\hline
\end{tabular}

5 Odkazy k poznámkám a bibliografie

Egeland, J., \& Fallmyr, Ø. (2010). Confirmatory factor analysis of the Behavior Rating Inventory of Executive Function (BRIEF): Support for a distinction between emotional and behavioral regulation. Child Neuropsychology, 16(4), 326-337. https://doi.org/10.1080/09297041003601462

Fournet, N., Roulin, J.-L., Monnier, C., Atzeni, T., Cosnefroy, O., Gall, D., \& Roy, A. (2014). Multigroup confirmatory factor analysis and structural invariance with age of the Behavior Rating Inventory of Executive Function (BRIEF)-French version. Child Neuropsychology, 21(3), 1-20. https://doi.org/10.1080/09297049.2014.906569

Gioia, G. A., Isquith, P. K., Guy, S. C., \& Kenworthy, L. (2015). Behavior Rating Inventory of Executive Function, Second Edition. Psychological Assessment Resources.

Gioia, G. A., Isquith, P. K., Retzlaff, P. D., \& Espy, K. A. (2002). Confirmatory factor analysis of the Behavior Rating Inventory of Executive Function (BRIEF) in a clinical sample. Child Neuropsychology, 8(4), 249-257. https://doi.org/10.1076/chin.8.4.249.13513

Huizinga, M., \& Smidts, D. P. (2011). Age-related changes in executive function: A normative study with the Dutch version of the Behavior Rating Inventory of Executive Function (BRIEF). Child Neuropsychology, 17(1), 51-66. https://doi.org/10.1080/09297049.2010.509715

Christ, S. E., Huijbregts, S. C. J., de Sonneville, L. M. J., \& White, D. A. (2010). Executive function in early-treated phenylketonuria: Profile and underlying mechanisms. Molecular Genetics and Metabolism, 99, 22-32. https://doi.org/10.1016/j.ymgme.2009.10.007 
Lyons Usher, A. M., Leon, S. C., Stanford, L. D., Holmbeck, G. N., \& Bryant, F. B. (2016). Confirmatory factor analysis of the Behavior Rating Inventory of Executive Functioning (BRIEF) in children and adolescents with ADHD. Child Neuropsychology, 22(8), 907-918. https://doi.org/10.1080/09297049.2015.1060956

Marko, M. (2016). Využitie a zneužitie Cronbachovej alfy pri hodnotení psychodiagnostických nástrojov. Testfórum, 5(7), 99-107. https://doi.org/10.5817/TF2016-7-90

Milke, R. M. (2015). Working memory: The concurrent validity of the Behavior Rating Inventory of Executive Function and the relationship between parent and teacher ratings and performance-based measures [Dizertační práce]. Indiana University.

Peters, C., Algina, J., Smith, S. W., \& Daunic, A. P. (2012). Factorial validity of the Behavior Rating Inventory of Executive Function (BRIEF)-Teacher form. Child Neuropsychology, 18(2), 168-181. https://doi.org/10.1080/09297049.2011.594427

Stuss, D. T., \& Benson, D. F. (1986). The frontal lobes. Raven Press.

Vriezen, E. R., \& Pigott, S. E. (2002). The relationship between parental report on the BRIEF and performance-based measures of executive function in children with moderate to severe traumatic brain injury. Child Neuropsychology, 8(4), 296-303. https://doi.org/10.1076/chin.8.4.296.13505

Welsh, M. C., Pennington, B. F., \& Groisser, D. B. (1991). A normative-developmental study of executive function: A window on prefrontal function in children. Developmental Neuropsychology, 7(2), 131149. https://doi.org/10.1080/87565649109540483

\section{Měřené konstrukty:}

Klinické škály:

Inhibice, Přesun pozornosti, Emoční kontrola, Iniciativa, Pracovní pamět', Plánování a organizace, Organizace pomůcek a Kontrola chování. Klinické škály tvoří dva dílčí indexy - Index regulace chování (Inhibice, Přesun pozornosti, Emoční kontrola) a Index metakognice (Iniciativa, Pracovní pamět', Plánování a organizace, Organizace pomůcek a Kontrola chování) - a jeden celkový skór Globální exekutivní kompozit.

Validizační škály:

Škála inkonzistence a Škála negativity 